\title{
Az ígéret beszédaktusának vizsgálata a mai magyar nyelvhasználatban
}

\author{
Nowosielski Diána \\ SZTE Általános Nyelvészeti Tanszék
}

\begin{abstract}
Összefoglaló
Ebben a tanulmányban az ígéret beszédaktusát vizsgálom elméleti és gyakorlati megközelítésben. Az elméleti rész a föbb hagyományos és az újabb megközelítéseket is tartalmazza, az empirikus rész pedig egy diskurzuskiegészítéses teszt elvégzése volt. Megvizsgáltam az ígéret és a jóvátevés jelensége közötti kapcsolatot, valamint az őszinte és az őszintétlen ígéretek problémájára is rávilágítottam. A teszt kiértékelésével megállapítottam, hogy a mai magyar nyelvhasználatban milyen típusú ígéreteket használnak az egyetemisták, illetve néhány szociális tényezőn keresztül bemutattam az ígéret megjelenését különböző szituációtípusokban. Négyféle ígérettípust azonosítottam: arculatvédő, jóvátevő, visszautasító és feltételes ígéretek. Ezeket vizsgáltam szociális távolság és szociális státusz szerint. Nem elhanyagolható eredménye a tanulmánynak, hogy az ígéret gyakran nem önmagában, hanem valamely más aktussal egy szekvenciát alkotva fordul elő a nyelvhasználatban.
\end{abstract}

Kulcsszavak: beszédaktusok, ígéret, jóvátevés, őszinte ígéret, diskurzuskiegészítéses teszt

\section{Bevezetés ${ }^{1}$}

Tanulmányomban a nyelvészeti pragmatika beszédaktusokkal foglalkozó elemzéseit tanulmányozom, valamint egy illokúciós aktust elemzek a mai magyar nyelvhasználatban. Célom, hogy egy olyan beszédaktust vizsgáljak meg a magyarban, az ígéretet, amelyet még nem kutattak behatóan, egy olyan módszerrel, a diskurzuskiegészítéses teszttel (DCT), amely lehetővé teszi az összehasonlítást egyéb nyelvek ugyanilyen típusú beszédaktusaival.

Kutatásom során nem találkoztam az ígéret aktusával foglalkozó magyar szakirodalommal, s ennek empirikus megközelítése, különösen DCT-tesztes vizsgálatú tanulmány még a külföldi szakirodalomban is nagyon ritka. Vizsgálatom azonban nem teljes körü, mivel elsősorban a mai magyar egyetemistákat céloztam meg, ennélfogva a szituációk kialakításakor is arra törekedtem, hogy a számukra természetesebb élethelyzeteket jelenítsem meg. Így nem kerülhetett sor az összes szituációs változó szerepeltetésére. Nem tartalmaz továbbá olyan szituációt sem a teszt, amely nem valamely normaszegéssel kapcsolatos, ugyanis a szituációk megalkotásánál a normák megsértése mint kiindulási alap tűnt a legegyszerübb,

${ }^{1}$ A cikk elméleti része a Nowosielski (2015a) és Nowosielski (2015b) tanulmányok továbbfejlesztése. 
leghétköznapibb helyzetnek az ígéret előcsalogatásakor. Mivel a szituációkat tematikusan választottam ki, és utóbb változtattam a paramétereken (pl. szociális státusz és erő, valamint távolság), így a kapott adatok nem mutatnak mindenhol teljes képet. Nem elemeztem statisztikai programmal az eredményeket, elsősorban túlnyomórészt kvalitatív módszerrel végeztem a vizsgálatot. Elemzéseim számos utat nyitnak a további vizsgálódásokhoz.

Tanulmányomban nemcsak a beszédaktus-elméletben klasszikusnak számító, hagyományos - austini (Austin 1962/1990) és searle-i (Searle 1969/1997) - elméleteket tekintem át, hanem olyan, viszonylag újabb megközelítésekkel is foglalkozom, mint Hickey (1986) tanulmánya, vagy a különféle (ghánai afrikai, jordániai arab) kultúrákban az ígérés aktusának természetét kutató Inge Egner, Tun Nur Afizah Zainal Ariff és Ahmad Ibrahim Mugableh vizsgálatai (Egner 2002; AriffMugableh 2013). A részletes szakirodalmi ismertető után pedig saját kutatásomat, annak módszertanát és eredményeit fejtem ki.

Tanulmányom felépítése a következő: a 2. pontban bemutatom a beszédaktuselméletet, azon belül is előbb Austin, majd Searle vonatkozó munkásságát (Austin 1962/1990; Searle 1969/1997). Miután áttekintettem Searle taxonómiáját, egy újabb megközelítéssel, Hickey tanulmányával folytatom (Hickey 1986). A következő fejezetben (3.2. pont) az empirikus kutatás módszertanát ismertetem, a CCSARP-t, valamint a diskurzuskiegészítéses tesztet. Ezután az ígéret megjelenésének problémáival és más beszédaktusokkal való kapcsolatával foglalkozom a 4. pontban. Az 5. pontban ismertetem jelen kutatásomat, a 6 . pontban összegzem az eredményeimet. A 7. pontban összefoglalom tanulmányomat, a Függelékben pedig megtekinthető a kutatáshoz készített teszt.

\section{A beszédaktusokról}

A beszédaktus-elmélet a nyelvészeti pragmatika kiemelten kutatott ágazata. Magát a fogalmat így írja le Szili (2004: 65): „A beszédaktus nyelvi cselekedeteink legkisebb, önálló funkcióval bíró egysége."

\subsection{Austin (1962/1990) elmélete}

A beszédaktus-elméletet J. L. Austin alkotta meg, aki meghatározta az alapfogalmakat. Megkülönböztette a konstatívumokat és a performatívumokat, megalkotta a beszédaktusok hierarchikus hármas szerkezetét (lokúciós, illokúciós és perlokúciós aktusok) és osztályozását. Ezek közül a performatív megnyilatkozásokat emelném ki, melyeket „nem azért használunk, hogy leírjuk velük a valóságot, hanem, hogy változtassunk rajta” (Szili 2004: 72). Vagy más szavakkal: „a mondat kimondása (...) nem leírása annak, hogy mi mondható arról, amit akkor teszek, amikor ezt mondom ki, nem is annak leszögezése, hogy csinálom, hanem maga a csinálás" (Austin 1962/1990: 33). Austin a performatívumokat öt osztályba sorolta, melyek a következők: ítélkezők, végrehajtók, elkötelezők, viselkedők és bemutatók. Ezek közül az ígéret az elkötelezők csoportjában foglal helyet, mely aktusok kimondása során a beszélő elkötelezi magát egy cselekvés végrehajtására (Austin 1962/1990). Például: ígér, felvállal, megfogad, szavát adja stb. Austin nevéhez fűződnek még az ún. boldogulási feltételek (felicity conditions), amelyek a sikeres beszédaktusok létrehozásának feltételeit jelentik (Szili 2004). 


\subsection{Searle (1969/1997) megközelítése}

Austin megállapításai ma is használhatók egy-egy beszédaktus leírásakor, azonban tanítványa, John R. Searle munkássága is elengedhetetlen egy árnyaltabb elemzéshez. Bár Searle (1969/1997) máshogy osztályozta az illokúciós aktusokat mint Austin, az ígéret aktusa az elkötelezők vagy komisszívok csoportjába került, ahogy Austinnál is. A searle-i osztályozás (Searle 1976: 1) az illokúciós aktusok lényegének, a szavak és a világ közötti irányultságnak és a kifejezett pszichikai állapotnak a függvényében állapítja meg a beszédaktusok csoportjait: asszertívok, direktívák, komisszívok, expresszívák és deklaratívák.

Az illokúciós aktusok konkrét kontextusban, meghatározott feltételek mellett, a beszélő meghatározott intenciójával valósulnak meg. Vegyük az ígéret aktusát (Searle 1969/1997: 45-50).

\section{Az ígéret sikerességi feltételei:}

$\mathrm{S}$ - (speaker) beszélő, H - (hearer) hallgató, T- mondat, $\mathrm{p}$ - propozíció, A - aktus

(1) Megígérem, hogy holnap elmegyünk kávézni.

Ha van egy $\mathrm{S}$ beszélö, aki egy $\mathrm{H}$ hallgató jelenlétében $\mathrm{T}$ mondatot ejt ki, akkor T szó szerinti kimondása esetén $S$ őszintén és elégtelenségektől mentesen ígéri meg $\mathrm{H}$-nak, hogy $\mathrm{p}$, akkor és csak akkor, ha az alábbi feltételek teljesülnek:

1. „Az input és output feltételek normálisak.”

\section{Propozíciós tartalmi feltételek (2-3.):}

2. S beszélő a „T kiejtése által fejezi ki, hogy p”.

3. „P kifejezése által S álítja (predikálja) S egy jövőbeli A aktusát."

Előkészületi feltételek (4-5.):

4. „H előnyben részesíti azt, hogy $\mathrm{S}$ megteszi A-t, azzal szemben, hogy $\mathrm{S}$ nem teszi meg $A$-t, és $S$ is meg van győződve arról, hogy $H$ előnyben részesíti $A$-t, azzal szemben, hogy nem teszi meg A-t."

5. S és H számára nem nyilvánvaló, hogy normális körülmények között $S$ meg fogja tenni A-t.

\section{Őszinteségi feltétel (6.):}

6. S-nek szándéka, hogy megteszi A-t.”

Lényegi feltétel (7.):

7. S-nek szándékában áll, hogy T kimondásával kötelezettséget vállal A megtételére.

8. „S-nek szándékában áll $\left(\mathrm{i}_{1}\right)$, hogy $\mathrm{H}$-nak tudomására $(=\mathrm{K})^{2}$ hozza azt, hogy $\mathrm{T}$ kimondása egyenértékű azzal, hogy $\mathrm{S}$ A megtételére kötelezettséget vállal. Snek szándékában áll $\left(\mathrm{i}_{2}\right)$ az, hogy $\mathrm{K}$-t $\mathrm{i}_{1}$ felismertetése által érje el, és az is

${ }^{2} \mathrm{i}=$ szándék, $\mathrm{K}=$ tudomás 
szándékában áll $\left(\mathrm{i}_{3}\right)$, hogy $\mathrm{i}_{1}$-t $\mathrm{H}$ a kimondott $\mathrm{T}$ mondat jelentésére vonatkozó ismerete révén fogadja el."

9. S és H által beszélt »dialektus « szemantikai szabályai olyanok, hogy T-t akkor és csak akkor lehet pontosan és őszintén kimondani, ha 1-8. feltételek teljesülnek."

Ebből a propozícióhalmazból Searle levonta az ígéret aktusára vonatkoztatható használati szabályokat, amelyek segítségével az illokúciós erőt vizsgálta. Ezek a szabályok, ahogy Searle is írja (1969/1997: 51), sorrendezettek, tehát egymásra épülnek. Bár Searle a propozícióhalmazból vonja le a szabályokat, lényegüket tekintve az egyes feltételek tulajdonképpen ugyanazt álítják, mint az azokból levonható szabályok, csak jóval direktebbek, részletesebbek és konkrétabbak. Mindenesetre, ha el akarjuk különíteni az illokúciós aktusokat, mind a feltételek, mind a belölük képzett egzakt szabályok teljes körű ismerete szükséges, hogy megpróbáljuk minél pontosabban körülhatárolni az adott beszédaktusokat. Nem véletlen a „megpróbáljuk" kifejezés, hiszen a hétköznapi kommunikációban nagyon gyakori, hogy nem találunk vegytiszta beszédaktust egy-egy megnyilatkozásban. Searle és Vanderveken (1985) szerint a beszélő egy megnyilatkozása alkalmával egyszerre több illokúciós aktust hajthat végre. Ezek alapján feltételezhető, hogy az általam elemzendő aktus, az ígéret, önmagában ritkán fog előfordulni, inkább szekvenciaszerüen, más aktusokkal való együttes előfordulása a jellemző.

Searle taxonómiája sok szempontból nem alkalmazható az empirikus beszédaktus-kutatásban. Searle a beszédaktus-elméletet úgy alkotta meg, hogy az angol nyelvből kiindulva általánosított, s nem tesztelte valódi adatközlőkkel állításait. Így deduktív módon generált, saját intención és intuíción alapuló kutatásról van tehát szó, mely szilárd kiinduló alapokat nyújtott a beszédaktus-kutatásnak, viszont az elmúlt évek empirikus vizsgálatai alapján nem tekinthető maradéktalanul helytállónak. Például a 3. (propozíciós tartalmi) feltétel némely, általam vizsgált szituációban nem teljesül maradéktalanul, a 11. (kistestvér/ játék) szituációban (ahol a kistestvér egy játékért könyörög a beszélőnek) ${ }^{3}$ született Hátha szülinapodra teljesül a kívánságod vagy Várj még egy kicsit vele, tudod, hogy nemsoká ott a szülinapod! Addig beéred egy fagyival? megnyilatkozások, amennyiben indirekt ígéretnek minősülnek, megkérdőjelezhető, hogy a propozícióval teljes mértékben azt implikálja a beszélő, hogy megveszi neki az ajándékot. A beszélők mindkét válaszban az elhomályosítás eszközét választották arra, hogy intenciójukat elfedjék. Ez kapcsolatba hozható a lényegi feltételekkel, miszerint mintha nem teljesen akarnák szándékossá tenni a jövőbeli cselekedetet, fenntartva ezzel a későbbi változtatás jogát. Ennek ellenére mindkettő (és a többi, ezekhez hasonló, nagyon burkolt megnyilatkozás) mégis ígéretnek minősíthető - bár nem a searle-i formában. A harmadik, előkészületi szabály szerint csak akkor nyilatkozható az ígéret, ha normális esetben nem tenné meg a cselekedetet a beszélő. Adataim, nyelvi intuícióm és az általam olvasott szakirodalom (pl. Hickey 1986) szerint ez nem ilyen szigorúan működik a valóságban. Vélhetően sok nyelvben, de a magyarban bizonyosan találhatunk példát arra, hogy úgy tesznek fogadást, kötelezettségvállalást az emberek, hogy előtte már tervben

${ }^{3}$ A szituáció részletes leírását lásd a Függelékben. 
volt a cselekvés megtétele. Ez olyankor következhet be, amikor a hallgató számonkérte a beszélőt, hogy megtett / nem tett meg valamit, aminek ellenkezőképpen kellett volna történnie, s erre a beszélő egy jóvátevési aktus keretében megígéri, hogy legközelebb nem teszi meg, vagy éppen megteszi a kívánt aktust. Erre számos mintát találhatunk az 5. (Könyvtáros/könyv) szituáció (amelyben az elfelejtett könyveket kéri vissza a könyvtáros) ${ }^{4}$ válaszai között, pl. Ne tessék haragudni, holnap visszaviszem. Tehát az „események szokásos menetében” az adatközlőnek meg kellett volna tennie A-t (hogy visszaviszi a könyveket a könyvtárba), de mégsem tette, ettől függetlenül még ígéretnek számít. Ami viszont a leginkább szembetűnő probléma Searle elméletében, az az őszinteség kérdése. Erre a 4.2. pontban térek ki részletesen.

\subsection{Az ígéret aktusának megközelítése (Hickey 1986)}

Raymond Hickey A promise is a promise tanulmányában (Hickey 1986: 69-80) egy másfajta, gyakorlatiasabb módon közelíti meg az ígéret, az ő terminológiájában: kötelezettségvállalás (commitment) aktusát. Hickey három dologgal foglalkozik cikkében, (1) a szóbeli kötelezettségvállalás (verbal commitment) természetével, azaz: hogyan manifesztálódik mint beszédaktus, és az angol nyelvben hogyan jelenik meg, (2) a szerencsefeltételek vizsgálatával, és (3) a kötelezettségvállalás beszédaktusa és a többi beszédaktus közötti kapcsolattal. Együtt kezeli ezeket a jelenségeket, amelyek összefüggnek egymással, mint ahogy az ígéret beszédaktusa is rengeteg külső, nyelven kívüli tényezőtől függ. Habár a beszédaktusok lényege, ahogyan Hickey fogalmaz, hogy olyan performatív igével fejezzük ki őket, amelynek perlokúciós ereje van, a kötelezettségvállalás számos egyéb, indirekt módon is kifejezhető (Hickey 1986: 69). A kötelezettségvállalás fogalmát így definiálja: „Az elköteleződés alapvetően egy embernek a „kötődése”, hogy végrehajtson egy bizonyos cselekedetet. Ez a kötődés általában morális természetü, amit úgy lát az ember, hogy neki erkölcsi felelőssége, hogy teljesítse azt, amire önmaga kötelezte magát." 5 (Hickey 1986: 70), azaz egy olyan tett, ahol az egyén morális okokból köti magát egy bizonyos cselekedet megtételéhez. Persze ez lehet legális felelősségvállalás is, erre hívja fel figyelmünket a szerző. Ahogy sok beszédaktusnál, itt is kötelező „elem” a hallgató, aki verbálisan passzív résztvevője a kötelezettségvállalás aktusának, de az ő percepciója mellett a jóváhagyása szükséges, hogy sikeres legyen az ígéret (Id. Searle 1. sikerességi feltétele). Hickey utal Searle általam is ismertetett tanulmányára, azonban a konkrét példákat hiányolja belőle (Hickey 1986: 71). Hickey elsőként a direkt ígérettel foglalkozik (Hickey 1986: 71), pl.

(2) I promise not to forget your birthday.

'Ígérem, nem fogom elfelejteni a születésnapodat.'

Ebben a megnyilatkozásban jól látszik a performatív promise 'ígér' ige, és bár nincsen kontextus, de ahogy Hickey írja, ebben az esetben érvényesül, hogy bizonyos nyelven kívüli tudás is közrejátszik, hogy ti. az emberek (ismerőseink,

\footnotetext{
${ }^{4}$ A szituáció részletes leírását lásd a Függelékben.

${ }^{5}$ Commitment is basically the binding of oneself to a certain course of action. This bindig is usually of a moral nature, that is one sees it as one's moral responsibility to fulfill that to which one has committed oneself. (saját fordítás)
} 
hozzátartozóink) születésnapját illik megjegyezni. Ez olyan közös tudásra vagy világtudásra épül, amit minden beszélő és hallgató ismer egy adott kultúrában. Az ígéret ezen típusát megelőző kötelezettségvállalásnak (prophylactic commitment) nevezte el. Hickey példákkal illusztrálja a negatív konnotációjú, ironikusan ható (pl. Ígérem, elfelejtem a születésnapodat), vagy a negált igével kifejezett (pl. nem fogok emlékezni), de pozitív konnotációjú direkt ígéreteket. Hangsúlyt fektet az olyan igealakokra, amelyek valamelyest felelősség- vagy kötelezettségvállalást fejeznek ki. llyenek pl. az accept 'fogad, elfogad' és az assure 'meggyőz, biztosít' igék az angolban. $A z$ ezekhez kapcsolódó példamondatokban gyakran áll mögöttük a responsibility, azaz 'felelősségvállalás' szó. Ám ezek a megnyilatkozások nem tartalmaznak beszédaktust, hiszen nem egyes szám első személyben, jelen időben íródtak, csupán egyszerü kijelentéseknek számítanak. Viszont az, hogy „I assure you l'll be there on time" (Hickey 1986: 74), azaz 'Biztosítom, hogy időben ott leszek', már sokkal érdekesebb: nemcsak, hogy beszédaktus, de a magyarban is tudunk hasonlót mondani:

(3) Biztosítalak, hogy nem fogsz kárt szenvedni.

Hickey megjegyzi, hogy az angolban van verbális és financiális kötelezettségvállalás, az előbbit az assure 'meggyőz, biztosít', míg az utóbbit az insure 'biztosít' fejezik ki, valamint egy olyan, harmadik fajta kötelezettségvállalás is van, az ensure 'biztosít, gondoskodik', amelyben a beszélő megnevezi a feladatot, amit elvállalt (Hickey 1986: 74). Vagy egy másik kifejezéssel, ami szintén előfordul ígéretként a magyarban is: szavamat adom.

Hickey ezután olyan igéket sorol fel egyes megnyilatkozásokban, amelyek nagyon hasonló jelentésük ellenére mégsem fejezik ki az elköteleződést, az ígéretet. Ezeket többnyire a magyarban is használjuk, pl. offer 'felajánl', volunteer 'önként felajánl', dedicate 'ajánl', undertake 'elvállal, magára vállal', melyek valamilyen önkéntes felajánlást, magára vállalást jelentenek, a swear 'megesküszik, esküvel fogad' és a vow 'esküszik, bizonygat, megfogad', amelyekkel esküt lehet tenni, vagy a guarantee 'biztosít, garantál' és a pledge 'leköt, elkötelez, megígér', amelyek a magyarban a biztosít, kezeskedik igékkel rokonok. Ezek csak azért nem fejeznek ki Hickey-nél 'commitment'-et, mert nem a performatív igés alakok szabályai szerint említi őket. Az ígéret aktusa csak és kizárólag akkor lép tehát érvénybe, amikor a beszélő egyes szám első személyben, kijelentő mód, jelen időben teszi a megnyilatkozást, ami a jövő időre vonatkozik, stb. (I. Searle 2. és 3. sikerességi feltételei és 1-3. szabályok).

Ezután Hickey a nem komisszív igéket vizsgálja meg, amelyek gyakorlatilag az ígérés indirekt beszédaktusai. Az indirekt ígéretek olyan igét tartalmaznak, melyek a beszélő egy bizonyos viselkedésre utaló szándékát fejezik ki. Ám itt is kiderül, hogy csak a feltételek hiánytalan megléte eredményezheti a sikeres beszédaktust. Ami még nem elhanyagolható Hickey tanulmányából, az a kötelezettségvállalás és a bocsánatkérés (vagy jóvátevés) beszédaktusa közötti szoros kapcsolat említése. „A mentegetőzés/bocsánatkérés kifejezése után helyes (adekvát) a személyes elköteleződés/ígéret, habár az ígéret úgy tűnik, hogy megsérti az őszinteségi 
feltételt, tehát inkább sugall egy egyszerű óhajt, hogy lecsitítsa/megnyugtassa a partnerét, mintsem hogy megismételje a sértő cselekedetet."” (Hickey 1986: 78)

A Hickey-tanulmány valóban jobban épít arra, hogy több adattal támassza alá elméletét, míg az absztraktabb Searle-cikk nem, így egymást kiegészítve széleskörü alapot, megfelelő támpontot adnak a további vizsgálataimhoz. A Hickey-cikk további előnye a kutatásom számára, hogy rávilágított arra, hogy az ígéret megnyilatkozásának eszköztára mennyire változatos. Továbbá arra a nem elhanyagolható következtetésre sarkallt, hogy a jóvátevés és az elköteleződés szoros kapcsolatban állnak egymással, ezt a 4.1. pontban ki is fejtem részletesen.

\section{Az ígéret aktusának empirikus vizsgálati lehetőségei}

\subsection{A beszédaktus-kutatás}

Kutatásom számomra legizgalmasabb és egyben legnehezebb része az adatgyűjtés. Ha empirikus nyelvészeti kutatást végzünk, többféle módszerből válogathatunk. $A$ legmegbízhatóbb elemzéshez természetes, spontán nyelvi kommunikációs adatforrás szükséges. Azonban ez a módszer „rendkívül időigényes, megnehezíti a kontextuális változók ellenőrzését, és nem feltétlenül biztosít hozzáférést minden olyan kontextushoz, amely a kutató számára érdekes lehet" (Suszczyńska 2003: 272). A szociopragmatika egyéb eszközökhöz szokott fordulni - ahogy Suszczyńska ismerteti -, szerepjátékhoz, telefonos kísérleti technikához (Turnbull 2001), vagy írásos és szóbeli diskurzuskiegészítéses teszthez. Habár a szóbeli, spontánabb adatforrások esetenként megnyerőbbnek tűnhetnek és több bizonyító erővel bírhatnak, nem biztos, hogy tartalmaznák az általam keresett beszédaktust, így az írásos diskurzuskiegészítéses teszt mellett döntöttem. Ahogy a szakirodalom is emellett érvel, én is a nagyobb és gyorsabb adatmennyiség gyűjtésére törekedtem, valamint nem utolsósorban ez költséghatékonyabb és kényelmesebb mód is, mint pl. egy Turnbullféle telefonos kísérlet. Ugyanezt a módot használja Szili Katalin is a kérés, az elutasítás, a bocsánatkérés és a bókra adott válaszstratégiák vizsgálására (Szili 2004).

A következő részben bemutatom a tanulmány módszertanának hátterét, a szociopragmatika beszédaktusokra specializálódott kutatásait, valamint az adatgyűjtési módszerek - azon belül is a diskurzuskiegészítéses teszt - tulajdonságait, hatékonyságát.

\subsection{A CCSARP}

A nemzetközi szociopragmatikai empirikus kutatások közül az első nagyszabású vállalkozás az 1980-as években kezdődött, vagyis pontosabban 1981-89 között (Suszczyńska 2010: 47). Ez a CCSARP (Cross-cultural Study of Speech-Act Realization Patterns) volt, amely több nyelvben vizsgálta a kérés (requesting) és a bocsánatkérés (apologizing) beszédaktusait azzal a céllal, hogy felfedjék a nyelvi

\footnotetext{
${ }^{6}$ The personal commitment after the expression of apology is appropriate, whereas the promise seems to violate a sincerity condition, i.e. it suggests a simple wish to silence the partner rather than as a promise not to repeat the offending action. (saját fordítás)

Hickey példamondata (Hickey 1986: 79 (33a)): Okay. I'm sorry, it won't happen again., magyarul: Oké. Bocsánat, nem fog többet elöfordulni.
} 
viselkedés univerzális tulajdonságait, valamint hogy melyek azok a nyelvspecifikus jelenségek, amelyek csak bizonyos kultúrákban fordulnak elő. Az eredeti céljuk az volt, hogy összemérjék a beszédaktusok elméleti tanulmányait az empirikus kutatásokkal, amelyek beszélt nyelvi adatokra épülnek. Suszczyńska (2010: 47) szerint így három célja volt a projektnek: kutatni a (1) kultúrák közötti eltéréseket, (2) szociopragmatikai eltéréseket, (3) nyelven belüli eltéréseket (pl. egyéni nyelvhasználat, anyanyelvi vagy nem anyanyelvi beszélö). A CCSARP hét különböző nyelvben (nyelvváltozatban) kísérelte meg összehasonlítani a kérés és a bocsánatkérés megnyilvánulásait. Kiderült, hogy habár mindkét aktus arculatsértő és valamilyen orvoslást, jóvátevést igényel, a kéréssel a B „terheli”, a bocsánatkéréssel viszont támogatja a $\mathrm{H}$-t, de hajlamos súlyosbítani a sértést. Észrevették, hogy vannak ún. szituációs változók: szociális (kontextuson kívüli) és kontextuális (kontextustól függő) faktorok, melyek erősen befolyásolják az adott beszédaktus megjelenési formáját. A szociális faktorok közé tartoznak a társadalmi erö/státusz és a szociális távolság, és még olyan individuális változók, mint a nem, a kor és az iskolázottság. A kontextuális faktorok viszont a beszédaktustól függnek, és a konkrét szituáció előfeltételeivel kapcsolódnak össze. Ezek a faktorok kultúraspecifikusak (Suszczyńska 2010: 48). Ezen változók a jelen kutatásban is jelentős szerepet játszanak, ugyanis az általam generált szituációkban a társadalmi szerepkörök és kapcsolatok (státusz és távolság) paramétereit úgy változtattam, hogy egy típusú kontextushoz legalább két olyan szituáció tartozzon, amelyekben különböző szociális paramétereket állítottam fel. Például, míg az első két szituációban arra voltam kíváncsi, hogy vajon a barátoknak vagy a tanárnak fognak többet ígérni a rossz referátumot készítő beszélők, addig a 3. (Tanár/késés) és a 4. (Főnök/késés) szituációkban az érdekelt, hogy lesz-e valamilyen különbség a szociális státusz szerint magasabban elhelyezkedő főnök és a tanár között.

Mivel a CCSARP kutatásnak az egyik célja az volt (azon kívül, hogy érintették az univerzalitás-kultúraspecifikusság máig tartó vitáját), hogy nagy mintát szerezzenek rövid idő alatt, így választaniuk kellett egy olyan tesztelési formát, amely illeszkedik az elvárásaikhoz. Ahogy Suszczyńska idézi Blum-Kulka és munkatársai munkáját: „Egy nagy mintát szerettünk volna kapni, hét országban, két jellegzetes beszédaktusra ugyanabban a kontextusban. Ez gyakorlatilag elképzelhetetlen lett volna terepen történő feltételek mellett. [...] Az összehasonlíthatóság igénye miatt ki kellett zárni az etnográfiai módszereket"7 (Blum-Kulka-House-Kasper 1989: 13). Tehát Blum-Kulka és mtsai szerint azért kellett kizárni az etnográfiai módszereket, mert az olyan, kvalitatív módszerrel végzett kutatások túl szubjektívek, és nem biztos, hogy a vizsgálati tárgyhoz kötődő adatokat generálnának. Ráadásul, ahogy arra a fejezet bevezető részében is kitértem, nincs garancia arra, hogy a felvett/rögzített anyagban nagy mennyiségben fordulna elő a kívánt válasz. BlumKulkáék abban is hittek, ahogy Suszczyńska bemutatja, hogy az írásbeli adatgyűjtő technikák használata nemcsak segíti kontrollálni a különböző szituációs változatokat, de több sztereotipikus választ nyernek ki vele, amelyek jobban feldolgozhatók

\footnotetext{
${ }^{7}$ We were interested in getting a large sample, in seven countries, of two specific speech acts used in the same context. This would have been virtually impossible under field conditions. [...] These demands for comparability have ruled out the use of ethnographic methods. (saját fordítás)
} 
a kultúrák közti összehasonlítás során. Így lett az írásos diskurzuskiegészítéses teszt (Written Discourse Completion Test/Task, rövidítve: DCT) a kutatásuk eszköze, amely 16 szituációt tartalmazott, amelyeknek a fele a kérés, a másik fele a bocsánatkérés kinyerésére irányult, az adatközlők pedig egyetemisták voltak hét országból. Amire Blum-Kulka és munkatársai (1989), Suszczyńska (2010) és én is figyeltem a kutatásomban az az, hogy azokat a szituációtípusokat, amelyek hétköznapi esetet jelenítenek meg, a nyugati kultúrákban bizalmasnak, ismerősnek kell, hogy érzékeljék a résztvevők, azonban az változó, hogy az adatközlők szerepköreinek kapcsolata hogyan, milyen szavakban nyilvánul meg (tehát hogyan változnak a válaszok, ha változnak a szociális faktorok paraméterei). Erre külön jelölést találhatunk: a beszélő és a hallgató közti társadalmi hierarchia (dominancia/társadalmi erő) dimenziójára a $\mathrm{B}<\mathrm{H}$ (amikor a beszélő társadalmi ereje kisebb a hallgatónál, pl. diák a tanárhoz képest), B>H (amikor a B magasabb társadalmi státusszal rendelkezik, mint a hallgató) vagy $\mathrm{B}=\mathrm{H}$ (amikor egy társadalmi szinten vannak) jelöléseket használták (használják ma is), a szociális távolság (Social Dimension) / bizalmasság (intimitás) dimenzióját pedig +/- SD-vel jelölték. (Suszczyńska 2010: 48-49).

A kultúraközi kutatások leggyakrabban alkalmazott vizsgálati fajtája tehát a DCT, azaz a diskurzuskiegészítéses teszt volt, amelyben szándékosan úgy alakították ki a kontextusokat, hogy azok mindegyik kultúrában hasonlóak legyenek (Suszczyńska 2010: 49), tehát minél jobban összehasonlíthatóvá váljanak. Pontosan ezen okból esett az én választásom is a diskurzuskiegészítéses tesztre. Egy írásbeli kérdőív minimális adatokat kér a válaszolóktól, mint életkor, nem, születési hely, végzettség, foglalkozás. Ezek alapján kategorizálhatjuk a születendő válaszokat, vizsgálhatjuk nemek vagy kor, iskolázottság szerinti megoszlásban a mért adatokat. A tesztnek annyi kérdést/szituációt kell tartalmaznia, amely már elég ahhoz, hogy releváns adatok születhessenek. A megfogalmazásban maximálisan ügyelni kell arra, hogy a nyelvész nem alkalmazhat „manipulatív” eszközöket, tehát jelen kutatás esetében jövő idejű utalásokat, direkt felszólítást az ígérésre, túl sok vagy bonyolult kontextust, amely beszükítené a válaszadás lehetőségét stb. Mindezek betartása mellett sem biztosított, hogy tökéletesen autentikus válaszok fognak születni, ám ezt elmondhatjuk akármelyik tesztről, amelyről az alanynak tudomása van. Mint ahogy már kifejtettem, a spontán adatok lekérése kockázatos és nem kifizetődő, hiszen természetesen egyrészt a személyiségi jogok megsértése miatt nincsen lehetőség ilyen vizsgálatokat végezni, másrészt viszont nem biztos, hogy tartalmaznák az általam vizsgált jelenséget.

Rátérve a vizsgált aktusra, a következő részben kifejtem, hogy milyen problémákkal kell szembenéznünk, amikor az ígéret aktusát kutatjuk a mai magyar nyelvhasználatban.

\section{Az ígéret aktusa}

\subsection{Az ígéret mint a jóvátevés egy eszköze}

A klasszikus beszédaktus-elméletben még nem ismerték fel a tényt, hogy a hétköznapi beszédaktusok nagyon gyakran nem önmagukban, hanem valamely más aktussal együtt, ún. szekvenciákban szoktak előfordulni: az ígéret például tipikusan 
a bocsánatkérés vagy jóvátevés aktusával (erről I. Fraser 1981; SearleVanderveken 1985; Hickey 1986). A szakirodalom alapján felállított előzetes hipotéziseim szerint különösen gyakran találunk jóvátevési aktussal együtt kötelezettségvállalást kifejező megnyilatkozásokat. Ezért fontos a jóvátevés aktusával foglalkozni ebben a részben.

A CCSARP osztályozási rendszerét sok éven át csak a bocsánatkérés beszédaktusára alkalmazták, módosítás nélkül használták a korábbi és a mostani tanulmányokat (Suszczyńska 2010: 49). Az osztályozás fejlődésével megpróbálták a bocsánatkérést mint stratégiák halmazát elemezni, ennek következtében érdekes megállapításokra jutottak. Suszczyńska (2010: 50) szerint ezek azon a feltételezésen alapszanak, hogy bocsánatkérést nem csak a bocsánat és a sajnálom kifejezésekkel mondunk, hanem másfajta megnyilatkozások is kifejezhetik ugyanezt a jelentést. Hasonló következtetésre jut a már említett Hickey (1986) is az ígérettel kapcsolatban.

Fraser 1981-es tanulmányában vizsgálta először a bocsánatkérés stratégiáit (Fraser 1981). Kilenc bocsánatkérő stratégiát vagy szemantikai formulát talált, ahol a stratégia a mondatok halmazára utalt, melyeknek mindegyike bizonyos szemantikai szempontoknak feleltethető meg. Ezek bármelyikét lehet használni arra, hogy végrehajtsuk a szóban forgó aktust, bár nem minden kontextusban lesznek megfelelőek. Az első négy stratégiában az adatközlői explicit módon kimondták a bocsánatkérés valamilyen formáját, (pl. I apologize for..., I must apologize for...), ezért direkt stratégiáknak nevezte el őket. Számunkra a maradék öt stratégia a fontos, amelyekben a beszélő nem említette, hogy bocsánatkérésről van szó. Ezek a stratégiák a következők voltak: (5) a támadás megbánásának kifejezése (I'm sorry 'sajnálom'), (6) elnézés kérése (excuse me 'elnézést', forgive me 'bocsásson meg'), (7) a támadás felelősségének bevallása, beismerése (that was my fault 'az én hibám volt'), (8) „promise of forbearance”, tehát a beszélő megígéri, hogy tartózkodik az ilyen cselekedetektől a jövőben (I promise it won't happen again 'ígérem, nem fog többet elfordulni'), és (9) jóvátétel felajánlása (let me pay for the damage 'engedd meg, hogy kifizessem a kárt') (Suszczyńska 2010: 50). Innentől kezdve ezek a kategóriák némi változtatással tovább fejlődtek, és a későbbi tanulmányokban is mindig felbukkan az ígéret mint a jóvátevési aktus egyik stratégiája.

Mivel az általam vizsgált 11, ígéretet kiváltó szituációból 9 tartalmaz valamilyen jóvátevési stratégiát, ezért fontosnak tartom foglalkozni a bocsánatkérésekkel. Fraser (1981) meghatározta, hogy melyek azok a faktorok, amelyek szerepet játszanak abban, hogy milyen bocsánatkérési stratégiát választunk:

1. az áthágás természete, pl. személyes vagy szociális normát sért,

2. az áthágás súlyossága, pl. enyhe behatolás (rossz szobába benyitni) vagy egy komolyabb behatolás (Suszczyńska 2010: 50), mint pl. órákig váratni valakit,

3. a szituáció típusa, amelyben megtörtént az áthágás, mint pl. informális vs. üzleti vagy szakmai szituációk,

4. a relatív viszony a $\mathrm{B}$ és a $\mathrm{H}$ között, a teljesen idegenektől a bizalmasokig váltakozva, és

5. a bocsánatkérő neme (Suszczyńska 2010: 51).

Érdekes, hogy amikor az ígéretet kiváltó szituációkon gondolkodtam, mindig valamilyen normasértés, arculatbántás, vagy valamilyen áthágás, behatolás jutott 
eszembe. S ezeket az elképzelt szituációkat változtattam különböző paraméterek szerint, legfőképp a társadalmi viszony mentén: főnök - szaktárs - barát - partner, tehát a szociális távolság és a hierarchia szerint. Hogy milyen eredmények születtek ezen faktorok figyelembe vételével, arról a 6.1.2. pontban számolok be.

\section{2. Ószinte vs. őszintétlen ígéret}

Kutatásom során újra és újra szembetalálkoztam azzal a kérdéssel, hogy mi számít őszinte ígéretnek. Meglepő, hogy a searle-i őszinteségi feltételt és szabályt nagyon gyakran megszegő eredményekkel találkoztam az adatgyűjtés során. Azt vettem észre, hogy a valós nyelvhasználatban rengetegszer teszünk olyan hirtelen ígéreteket, amelyeknek elsődleges célja például a $\mathrm{H}$ megnyugtatása, s nem foglalkoznak különösképpen a szándékkal, amellyel rendelkeznie kellene az ígéret kimondásakor. Searle szerint (Searle 1969/1997: 50) „hiányzik belőle a megígért aktus végrehajtására vonatkozó szándék. Viszont színleli azt, hogy ez a szándék megvan benne”. Azért, hogy az őszintétlen ígéreteket is ígéretnek vehessük, „csak annyit kell tennünk - írja Searle - hogy feltételeinket olyan formára alakítjuk át, hogy nem annyira a szándékkal rendelkezést állapítjuk meg, hanem azt, hogy a beszélő felelősséget vállal azért, hogy szándéka fennáll" (Searle 1969/1997: 50). Az általam gyűjtött adatoknál azonban az a személyes intuícióm, hogy a leírt ígéret se nem őszintétlen, se nem igazán őszinte. Habár a B látszólag nem foglalkozik azzal, hogy valóban megteszi-e majd az A-t, nem mondható el róla, hogy direkt hazudna $\mathrm{H}$-nak. Searle végül semlegesítette az ígéretet, s úgy írta át a 6 . feltételt, hogy az S csak felelősséget vállal a szándékára, de nem beszél arról, hogy őszinte-e a szándéka vagy sem. Inge Egner (2002) ghánai afrikai beszélők ígérési módszereit vizsgálva felfedezte, hogy az afrikai kultúrákban akkor is ígérnek, amikor nyilvánvalóan tudják, hogy nem fogják tudni betartani az ígéreteiket, csupán udvariassági szempontból teszik ezt. Tun Nur Afizah Zainal Ariff és Ahmad Ibrahim Mugableh is azt találták (Ariff-Mugableh 2013: 249), hogy az ígéretet tartalmazó megnyilatkozást lehet igaznak vagy hamisnak nevezni, mert bonyolult, egymással koherens szociális és pszichológiai tényezőket, az interakciós felek természetét, a megnyilatkozás kontextusát és a társalgás résztvevőinek szándékát (intention of interactants) is alaposan meg kell vizsgálni. Kutatási tárgyuk a jordániai arab beszélők ígéretet használó viselkedése, mely során kiderült, hogy a nyugati kultúrákkal szöges ellentétben az araboknál minden, elköteleződést sugalló kifejezéshez hozzáteszik, hogy ?inŠaallah, ami nagyjából annyit jelent, hogy 'ha Allah is úgy akarja'. Tehát mintha abszolút nem függne a beszélő intenciójától, csakis az isten akarata számítana. A jordániai arabok által produkált ígéretek egyik típusa az ún. hamis ígéret (false promises). Ez olyan állítást tartalmaz, amelyben valamely, az emberi élet számára lehetetlen dologgal álítják feltételbe az ígéretet. Ezt magyar példával is lehet illusztrálni:

(4) Akkor írom meg a házi feladatodat, ha piros hó esik.

Kapcsolódva a bocsánatkérésekhez, Fraser (1981: 265-266) különbséget tett a szívből jövő (őszinte) és a rituális bocsánatkérések között. Az utóbbit többnyire akkor alkalmazzuk, ha a környezet, szituáció vagy a közösség úgy kívánja. Suszczyńska (2010: 50) rámutatott arra, amit Fraser is beismert, hogy nem egyértelmű a megkülönböztetés a két perspektíva között, és vannak olyan 
bocsánatkérések, amelyeket mindkettő motivál. Az, hogy ezek hogyan kombinálódnak, illetve, hogy melyiket választják a beszélők, bizonyos körülményektől függenek. A rituális bocsánatkérés vagy rituális ígéret - ha feltételezzük, hogy van ilyen nagyon hasonló a helyzetmondatok egy típusához is. Erről Kecskés István azt írta, hogy a szakirodalom megkülönböztet rituális és rutin helyzetmondatokat (Kecskés 2003: 95). Habár, a rituális helyzetmondatok a nyelvi etikett részét képezve szinte kényszerszerüen keletkeznek, Kecskés szerint bizonyos kultúrákban (japán, török vagy arab) valóságos érzéseket fogalmaznak meg. „Az ilyen kifejezések szemantikailag általában sohasem üresek: a beszélök azt mondják, amit gondolnak" (Kecskés 2003: 95). Bár a magyarban nem jellemző, de rituális helyzetmondatnak tekinthetők az olyan jókívánságok, mint a Jó utat!, Sok sikert!, Jó éjszakát! stb. Kecskés (2003: 95) szerint a rutin HM-eket is szituációtól függően használjuk, de nem szükségszerűen. Gyakran előfordul az ilyen megnyilatkozásoknál, hogy eltér a kompozicionális jelentés és a tartalmi jelentéstől és amire valójában utalnak. A rutin HM-ek Kecskés szerint olyan, részben lexikalizálódott, metaforikus jelentésű, kultúraspecifikus konceptuális jegyek, amelyekben a lexikai tartalom szinte teljesen kiürül, s csupán a pragmatikai funkció válik érvényessé. llyenek a magyarban pl. Mivel szolgálhatok?, Hogy megy a sorod? Szemantikailag üresek, „mert a bennük szereplő szavak (sorod, szolgálhatok) fogalmi motiváltsága majdnem teljesen eltűnt belőlük" (Kecskés 2003: 96-99). Ezek a HM-ek szituációtól függenek, akárcsak az olyan ígéretek, amikor valamilyen arculatsértő cselekvésre olyan jóvátevési stratégiát hajtunk végre velük, amit csak az aktuális helyzet miatt teszünk meg. Ilyenek számos formában elöfordulnak az általam gyüjtött adatokban. Vegyük a 6. szituációban elhangzó (5)-öt!

\section{Bocsi, megígérem, hogy jövő hétre hozom. (...)}

\section{6. szituáció (Szaktárs/könyv)}

Az (5)-ben az adatközlő csak azért ígérte meg szaktársának, hogy visszahozza a könyvet, azért ajánlotta fel a jóvátevést, hogy a mindkettejük arculatát ért támadás megszünjön, vagy legalábbis enyhüljön. A szaktárs arculatát megsértette azzal, hogy elfelejtette a tulajdonát visszahozni, a beszélő viszont azáltal sérült, hogy a közösség szemében ő feledékenynek mutatkozott. A beszélő látszólag a hallgató érdekeivel törődik, de egyúttal a saját arculatát is próbálja helyreállítani. Mivel itt az arculatóvás stratégiáinak összjátéka irányítja a megnyilatkozást, nem igazi, őszinte ígérettel találkoztunk. Ha nem őszinte az ígéret, akkor ezzel megsértené az eredeti 6. searle-i feltételt? Feltételezhetjük továbbra is, hogy a searle-i ígéretfeltételek nem alkalmazhatók teljes mértékben, univerzálisan a gyakorlatban mért adatokra. Az a felfogás, miszerint meg kell különböztetni őszinte és őszintétlen ígéreteket, nem állja meg a helyét. Egyrészt, csupán a leírt (vagy esetleg szóban elhangzott) adatokból nem tudunk következtetni az adatközlő intencióira, akaratára, vagy arra, hogy őszintén gondolja-e vagy sem, amit kimondott (erre utalt Ariff és Mugableh (2013), hogy az ígéret egy nagyon bonyolult összetevőkből álló cselekvés). Éppígy nem lehet felosztani őszinte vagy hazug ígéretekre. Léteznek azonban nyilvánvalóan őszintétlen, hamis ígéretek (false promises) (ld. (5) példa), amelyek a szituációtól függően egyértelműen fals, nem őszinte vagy lehetetlen dolgokat ígérnek. Anyanyelvi intuícióim alapján sem a 6., sem a módosított, 6.a) searle-i feltételt nem 
tartom teljesen érvényesnek. Nemcsak a szándék, de maga a felelősségvállalás a szándék iránt is lehet hamis vagy őszintétlen. De mindaddig, amíg hazugságvizsgáló nem áll a nyelvész kutató rendelkezésére, teljes biztossággal nem állíthatjuk egy ígéretről, hogy igazi, őszinte szándékkal tette-e a beszélő vagy sem.

A szakirodalom ismertetése után három hipotézist állítottam fel a vizsgált aktussal és az elkészített szituációkkal kapcsolatban.

1. feltételezés: Azokban a szituációkban, ahol a H szociális státusza nagyobb, ott több ígéretet fognak közölni.

2. feltételezés: A hétköznapi, egyszerü szituációkban több ígéret lesz, mint az absztrakt és az intim helyzeteknél.

3. feltételezés: Az ígéret önmagában ritkán fordul elő, viszont egy másik aktus mellett (pl. jóvátétel, azon belül bocsánatkérés) nagyon gyakori lesz.

1. feltételezés: Fraser szerint az áthágás természetétől és súlyosságától is egyaránt függ, hogy milyen jóvátevő stratégiát választunk (Suszczyńska 2010: 50). Bár Suszczyńska nem fejezi ki expliciten, hogy a bocsánatkéréseknél a nagyobb szociális státusz minden esetben több bocsánatkérést vonzana, de találunk adatot arra vonatkozólag, hogy a 'hasonló tettektől való tartózkodás ígérete' (promise of forbearance) stratégiát abban a szituációban használták legtöbben, ahol az elkésést próbálták enyhíteni a főnöknél. Suszczyńska szerint ez azért van, mert ez a stratégia státusz-érzékeny (Suszczyńska 2010: 106). Az ígéret szempontjából ez nem elhanyagolható tény, ugyanis az ígéret gyakran jár együtt a jóvátevés valamelyik aktusával (vagy önmaga is annak egy stratégiája).

2. feltételezés: ${ }^{8}$ Szintén Fraser stratégiaelmélete (Suszczyńska 2010: 50) alapján feltételeztem, hogy a szituáció típusa és a $B$ és a $H$ közötti viszony is hatással van a választott stratégiára. $A z$, hogy milyen korosztálynak, illetve rétegnek mi számít hétköznapi szituációnak, korosztályonként és rétegenként eltérő. Feltételezhetően az adott korosztálynak, akik hasonló társadalmi szinten állnak, ugyanazok a típusú szituációk fognak ígéretet kiváltani.

3. feltételezés: Azt, hogy az illokúciós aktusok önmagukban ritkán fordulnak elő, már Searle és szerzőtársa, Vanderveken is megállapította (Searle-Vanderveken 1985: 11), erre majd a 6.1. pontban térek ki. Sőt, nemcsak Hickey (1986)-nál, de már Fraser (1981)-nél is láthattuk, hogy a jóvátevések egy társaktusaként jelenik meg az ígéret. Frasernél ez a 8. bocsánatkérő stratégia volt (Suszczyńska 2010: 50). A másik szerző (Hickey 1986: 78) később keletkezett cikkében viszont azt olvashatjuk, hogy a jóvátevés és a kötelezettségvállalás szoros kapcsolatban állnak egymással. A fentiekre alapoztam a harmadik hipotézist, hogy lesz olyan adatközlö, aki több aktust egyszerre használ.

8 Árvay Anett a 2015-ös Pragmatika kerekasztalon (Károli Gáspár Református Egyetem, Budapest, 2015. május 29.) egy személyes konzultáció keretében arra hívta fel a figyelmemet, hogy az egyszerü szituációknál valóban könnyebben keletkezik ígéret, mint a bonyolultaknál, ahol esetleg a megértésen múlik a szituációra adott válasz. 


\section{A kutatás}

\subsection{A tesztelés}

Az ígéret aktusának a mai magyar nyelvhasználatban való empirikus vizsgálatára összeállított írásbeli diskurzuskiegészítéses teszt 16 szituációból áll, melyek közül 11 olyan, ahol várható ígéret, 5 egyéb (bókra adott válasz, visszautasítás, bók/dicséret, köszönet, kérés). Az egyéb aktusokat tartalmazó kontroll szituációk azért szükségesek, hogy az adatközlő ne érezze egyhangúnak vagy nyomasztónak a tesztet, illetve kevesebb esélye legyen, hogy rájöjjön a céljára, és elkezdjen rutin válaszokat adni.

Az írásbeli diskurzuskiegészítéses tesztet 40 fiatallal töltöttem ki, akik mind a Szegedi Tudományegyetem hallgatói. Életkoruk 19-26 év, közülük 37 nő és 3 férfi. Többségében bölcsész hallgatók, akik azonban nem hallgatnak behatóbban nyelvészeti kurzusokat.

Bővebb információra jelen kutatásban nem volt szükségem, mert nem kifejezetten szociológiai vizsgálatot végeztem. Ezért nem kérdeztem meg sem a lakóhelyüket, sem az iskolázottságukat vagy munkahelyüket. Előbbit azért nem, mert nem célom nyelvjárásonként elkülöníteni a rendelkezésemre álló adatokat, utóbbit viszont feleslegesnek tartottam, tekintve, hogy mindannyian egyetemisták és humán szakosok (Bölcsészettudományi Kar hallgatói), tehát nincs különösebb rétegződés közöttük (pl. szaknyelv szerint).

\subsection{Kontextuális jellemzők}

Az alábbiakban részletesen ismertetem, hogy milyen kontextuális jellemzőkkel bírnak a vizsgálat során felhasznált szituációk. Úgy állítottam össze a tesztet, hogy tematikusan párba lehessen őket rendezni. Így: két szituációban az adatközlő azzal találkozhat, hogy rossz referátumot készített, és szaktársai (1. szituáció) vagy a tanára (2. szituáció) panaszt tettek erre; két szituációban késés következtében kirúgással fenyegették (a 3. szituációban a tanár, a negyedikben a főnöke); három szituációban valamiféle értéktárgybeli (könyv, ill. pendrive) tartozása van, amit felrónak neki (a könyvtáros, a szaktárs és a legjobb barát). A maradék négy feladatban egy-egy bensőségesebb kapcsolatot ábrázoló helyzetre kellett reagálnia (elárulja a partnere titkát, aki erre rájön; vissza kell utasítania a legjobb barátját; a párja barátja féltékenykedik, és az utolsóban a kistestvére követelőzik). A szituációcsoportokon belül az egyes helyzeteket az különbözteti meg, hogy bennük egy-egy szociális paramétert megváltoztattam, így egészen más helyzet alakulhatott ki. Például a tartozásos szituációknál (5-7.) egyszer a könyvtárnak, másik két alkalommal a legjobb barátnak és egy ismerős szaktársnak tartoztak valamivel, tehát a $\mathrm{B}$ és a $\mathrm{H}$ közötti szociális távolságot változtattam meg. 


\begin{tabular}{|l|l|l|c|}
\hline \multicolumn{1}{|c|}{ Szituációk } & $\begin{array}{c}\text { Probléma } \\
\text { típusa }\end{array}$ & Szociális távolság & $\begin{array}{c}\text { Szoc. erö } / \\
\text { státusz }\end{array}$ \\
\hline 1. szit. (Barátok/referátum) & Szakmai hiba & Barátok/Szaktársak & $\mathrm{B}=\mathrm{H}$ \\
\hline 2. szit. (Tanár/referátum) & Szakmai hiba & Diák-Tanár & $\mathrm{B}<\mathrm{H}$ \\
\hline 3. szit. (Tanár/késés) & Idő & Diák-Tanár & $\mathrm{B}<\mathrm{H}$ \\
\hline 4. szit. (Fönök/késés) & Idő & Alkalmazott-Főnök & $\mathrm{B}<\mathrm{H}$ \\
\hline 5. szit. (Könyvtáros/könyv) & Tartozás & Idegen & $\mathrm{B}<\mathrm{H}$ \\
\hline 6. szit. (Szaktárs/könyv) & Tartozás & Szaktárs & $\mathrm{B}=\mathrm{H}$ \\
\hline 7. szit. (Barát/pendrive) & Tartozás & Barát & $\mathrm{B}=\mathrm{H}$ \\
\hline 8. szit. (Partner/titok) & Árulás & Bizalmas & $\mathrm{B}=\mathrm{H}$ \\
\hline 9. szit. (Barát/sörözés) & Találkozás & Barát & $\mathrm{B}=\mathrm{H}$ \\
\hline 10. szit. (Partner/barát) & Feltétel & Bizalmas & $\mathrm{B}=\mathrm{H}$ \\
\hline 11. szit. (Kistestvér/játék) & Feltétel & Bizalmas & $\mathrm{B}>\mathrm{H}$ \\
\hline
\end{tabular}

1. táblázat. A szituációk típusai ${ }^{9}$

\section{A szakmai hibára utaló szituációk (1. és 2.)}

Az adatközlő (továbbiakban: B mint beszélő) mindkét esetben olyan szituációba kellett, hogy beleképzelje magát, amelyben ő korábban a hallgatóság (szaktársak és tanár) szerint rosszul végezte a rá kiszabott feladatot (a referátuma nem volt érthető, nem volt összeszedett stb.), s most újabb kiselőadás megtartása előtt áll. A szituációban csak annyi utasítást adtam, hogy hozza a hallgató(k) (továbbiakban $\mathrm{H}$ mint hallgató) tudomására, hogy ezúttal jobban felkészült. A két helyzet közötti különbség csupán a H személye, annak szociális távolsága a B-hez képest.

\section{1. szituáció (Barátok/referátum)}

40 adatközlőből 28 produkált indirekt ígéretet, a maradék öt kérés/felszólítást a hallgatóság felé, kettőben remélik, hogy jobb lesz a mostani előadás, ötben valamilyen állásfoglalást tesznek arra, hogy jobban felkészültek. Tíz indirekt ígéret tartalmaz valamilyen kérést vagy felszólítást a hallgatósághoz, egy pedig bocsánatkérést a megnyilatkozás elején. 23 esetben történt utalás a múltkori referátumra, ami mentegetőzésként, magyarázkodásként fogható fel. Gyakori elem az igyekszem, próbálok, megpróbálok stb. arculatvédő, a szándékot kifejező stratégia (összesen 26).

\section{2. szituáció (Tanár/referátum)}

Itt 20 ígéret született, köztük 1 direkt, a többi indirekt formában. A maradékban egy felhívás, 3 bocsánatkérés, 1 köszönet, 1 megnyugtatás és további 13 összetett, arculatóvást, mentegetőzést vegyesen szerepeltető megnyilatkozást azonosítottam. Itt csak 7 esetben történt a múltkori eseményre való utalás, helyette inkább a most, a mai órán, az ezúttal kifejezéseket használták. Érdekes, hogy ennél a szituációnál kevesebbszer használják a próbál és az igyekszik szavakat, de többször a remélemet, és a bocsánatkérés is előfordul már, amikből arra lehet következtetni, hogy a $\mathrm{B}$ és a $\mathrm{H}$ közötti szociális távolság és státusz különbsége megnyilatkozásaikban

${ }^{9}$ A táblázat ötletét teljes egészében Małgorzata Suszczyńska disszertációja adta (Suszczyńska 2010: 81. Table 4, DCT situations). 
is megmutatkozik. Amíg az 1. szituációban a B igyekszik érthetővé tenni magát, addig a 2.-ban magyarázkodik, mentegetőzik, s csak reméli, hogy ezúttal jobban fog teljesíteni.

\section{Az időre utaló szituációk (3. és 4.)}

Ez a szituációpár a késés problémájával foglalkozik. A 3.-ban a tanár fenyeget, hogy kirúg a szemináriumról, ${ }^{10}$ a 4.-ben a gyakorlati munkahelyen a főnök fenyeget kirúgással. Egyszerü, rövid, hétköznapi helyzetek, a válaszolók többnyire könnyen beleélték magukat. ${ }^{11}$

\section{3. szituáció (Tanár/késés)}

Ebben 30 ígéretet találtam, melyek közül négy direkt formában jelent meg. Összesen 29 jóvátevési aktust (konkrétan bocsánatkérést) számoltam a válaszokban, melyek közül: 18 elnézést, 7 sajnálom, 3 bocsánat és 1 ne haragudjon formában jelent meg. Ezek közül 22 ígérettel, a többi mentegetőzéssel, kéréssel vagy mással, de önmagában nem fordult elő. Csupán öt alkalommal jelent meg önmagában az ígéret. Kreatív megoldásokkal is találkozhatunk a válaszok között, pl. negatív udvariassági stratégiával (Nyugodtan!).

\section{4. szituáció (Főnök/késés)}

Ebben a szituációban lett az egyik legmagasabb az ígéretek száma (39 darab), ezek közül 7 áll direkt formában (közülük csak kettő áll önmagában), a 39-ből összesen 5 önállóan, 33 bocsánatkéréssel, 1 köszönettel fordult elő. A mentegetőzés mint arculatvédő stratégia itt is fellelhető. Összetett megvalósulások is előfordultak: Jó, tudom, sajnálom! Tényleg igyekszem, de ma sem sikerült beérnem. Többször nem fordul eló, ígérem! Az elején a B a saját arculatát védi, majd hozzátesz egy jóvátevési stratégiát, amivel kifejezi, hogy megbánta, amit tett. Ezután egy önvédelmi, magyarázkodó megnyilatkozás következik, s a végére nyomatékosítja jóvátevési szándékát a $\mathrm{H}$ számára egy direkt ígérettel. Azt hiszem, az ilyen és ehhez hasonló példákban bővelkedő szituációknál, mint a 3. és a 4., beszélhetünk az ígéretről úgy, mint promise of forbearance 'a hasonló tettektől való tartózkodás ígérete' (Fraser 1981), mely a jóvátevési aktust teszi nyomatékosabbá.

\section{Tartozást megjelenítő szituációk}

Ezekben a hétköznapi szituációkban a $\mathrm{B}$ tartozik valamivel $\mathrm{H}$-nak, amit a $\mathrm{H}$ éppen visszakérne. Úgy változtattam a szociális paramétereket, hogy az egyikben egy szociális státusz szerint magasabb ember, a könyvtáros legyen a $\mathrm{H}$, a másik kettőben viszont egyenrangú legyen B-vel. A 6. és a 7. szituáció abban különbözik egymástól, hogy azokban a szociális távolság paramétereit változtattam: a szaktárs szinte idegen, a legjobb barát pedig nagyon bizalmas kapcsolat.

${ }^{10}$ A 3 . szituáció azt a háttértudást implikálja, hogy a szemináriumokon a maximálisan megengedett hiányzás 2 vagy 3 , s ha a tanár a késést hiányzásnak veszi, vagy olyan jellegủ az óra, hogy szükséges az ottlét végig, akkor bizony kirúghatja onnan a hallgatót.

${ }^{11}$ Egyes adatközlők arra panaszkodtak, hogy nekik azért nem tetszett ez a szituáció, mert nem szoktak sosem késni, mások pedig azt írták a megjegyzésbe, hogy annyira életszerűek voltak a szituációk, hogy szinte látták maguk elött a történéseket. A kutatás egyik hátránya, hogy a kvantitatív vizsgálatok mellőzik az egyén preferenciáit. 


\section{5. szituáció (Könyvtáros/könyv)}

Itt 100\%-os az ígéretek aránya a válaszokban, azonban direkt ígéret nem fordul elő egyszer sem. Önmagában megközelítőleg hétszer fordul elő, azért nem pontos a számítás, mert szerepel némelyik előtt káromkodás (Basszus,...), vagy valamilyen deklaráció (Értettem,..., Rendben,..., Oké,...). 20 szerepel bocsánatkérési aktussal együtt (melyek közül leggyakoribb az Elnézést), 9 mentegetőzéssel vagy indoklással, 10-szer áll mellette köszönet. A fenti beszédaktusok nagyszámú együttes megjelenése jellemző ennél a szituációnál, tehát nem ritka az olyan megnyilatkozás, ahol pl. bocsánatot kér, mentegetőzik és ígér a B (csak ez a variáció ötször fordul elő).

\section{6. szituáció (Szaktárs/könyv)}

15 db ígéretet számolhatunk ennél a szituációnál, 3 adatközlőnél váltott ki direkt ígéretet. A válaszok összetettsége miatt nehéz volt a kategorizálás, továbbá olyan beszédaktusok vagy stratégiák is előkerültek, amelyek korábban nem, vagy amelyek a hagyományos (pl. austini) besorolásokba nem voltak beilleszthetők. Huszonhétszer jelenik meg a bocsánatkérés (legtöbbször a ne haragudj, és majdnem ugyanannyiszor a bocs), mely gyakran fordul elő valódi jóvátevés felajánlásával és mentegetőzéssel is. A szituáció alapkövetelménye, hogy a B visszautasítsa a $\mathrm{H}$-t egy meghatározott időre, ennek következtében többféle stratégiát választottak, különböző kombinációkban: bocsánatkérés + felajánlás, bocsánatkérés + ígéret, bocsánatkérés + mentegetőzés (és ezek együttes kombinációi), valamint még negatív udvariassági stratégia (pl. Ne legyél már ilyen stréber, ráér még a könyv egy hétig), kérés/felszólítás (pl. Írj rám a hétvégén, küldj egy üzenetet és nem fogom elfelejteni!), valamint legalább négy esetben hárít a $\mathrm{B}$, tehát valamilyen módon megőrzi a $\mathrm{H}$ kérésének a visszautasítását. Hárításnak vagy visszautasításnak vettem a következő és a hozzá hasonló megnyilatkozásokat: Figyelj, leghamarabb csak a jövő hétvégén tudom visszahozni, addig nem megyek haza. Jól látható, hogy a B csak indoklást tesz arra, hogy miért nem tudja most visszaadni a könyvet, de nem akarja kárpótolni $\mathrm{H}$-t semmivel, csupán informálja, hogy mikorra várható a tulajdonának a visszakapása.

\section{7. szituáció (Barát/pendrive)}

Ennél a szintén visszautasítást implikáló szituációnál az okozta a nehézséget, hogy számos olyan válasz született, amelyben nem egyértelmű, hogy felajánlás vagy valamiféle feltételes indirekt ígéret aktusával van dolgunk. ${ }^{12}$ Például ebben a két válaszban: (a) Most nem hoztam, de ha szükséged van rá a napokban, akkor hazaugrok érte és (b) Holnapra elhozom, ha nem találkoznánk össze, megcsörgetlek és visszaadom. Az (a) megnyilatkozás egy feltételes felajánlást tartalmaz, (ha beillesztjük a felajánlom, hogy... frázist a hazaugrok érte elé, akkor nyilvánvalóvá válik). Ezzel szemben egy hasonló szerkezetet láthatunk a (b) mondatban, de az elején egy indirekt ígérettel, és aztán a feltételes szerkezettel. Az ígéret kiterjed a feltételes részre, s emiatt már több lesz, mint felajánlás. Nem a H akaratától teszi függővé a cselekedet megtételét, hanem a körülményektől. Tehát akármi lesz, ő vissza fogja adni a pendrive-ot. 12 válaszadó értelmezte szó szerint a szituációt:

${ }^{12}$ Ezt a 6.1. pontban, az osztályozásnál tisztázom. 
visszaadták a kérdéses eszközt: pl. Itt van, köszi szépen, és volt, aki visszakérdezett: Milyen pendrive? Azok közül, akik úgy értették, hogy otthon felejtették, 17-en kértek bocsánatot, (mely gyakran együtt járt mentegetőzéssel), 12-en vállaltak elköteleződést valamilyen indirekt formájú ígérettel, 9-en kérték, hogy a H emlékeztesse őket, továbbá találkozhatunk a már említett felajánlásokkal, köszönettel és még bókkal/dicsérettel is. A bocsánatkérés során itt is többször alkalmazták a $\mathrm{Ne}$ haragudj formulát, mint a bocsi-t, de volt nézd el és sorry alakú is, melyek a jóvátevés aktusának sokszínű megjelenési formáját példázzák.

\section{Bensőségesebb kapcsolatot ábrázoló szituációk}

Ezek a szituációk abban hasonlítanak egymásra, hogy nem annyira egyszerü, hétköznapi helyzetet teremtenek, hanem általában bizalmasabb jellegű (tehát kisebb szociális távolságot megjelenítő) körülményt. A 8. szituáció egy nagyon erős jóvátevést vár el az adatközlőtől: a partnere megtudta, hogy kifecsegte a titkát. ${ }^{13}$ A 9 -es szituáció szabadabb válaszlehetőségeket kínál: a $\mathrm{H}$ (legjobb barát) találkozót kér a B-től, aki jelenleg nem ér rá, de tudja, hogy mikor lesz legközelebb ideje. A válaszadótól függ, hogy hogyan utasítja vissza, és az is, hogy meg akarja-e nyugtatni a $\mathrm{H}$ t egy ígéret vagy felajánlás segítségével. A 10. feladatban egy nagyon konkrét helyzettel találkozhatott az adatközlő: a párja legjobb barátja féltékenykedik rá, s a párjának tudomására kell hozni, hogy csak akkor lesz kedves a baráthoz, ha ő is kedves lesz hozzá. Itt ugyan kihagyhatatlan volt a feltétel beillesztése, ez valószínüleg a válaszokat is befolyásolhatta, ám kérdéses, hogy milyen stratégiát használtak a beszélők. Az utolsó szituáció is eléggé absztrakt: a kistestvér egy játékért könyörög, amit jelenleg nem tud a $\mathrm{B}$ megvenni neki, viszont a $\mathrm{H}$ szülinapja közeleg. Tudasd vele, hogy arra megveszed - instrukcióval egyértelműsítettem a feladatot, de nem határoztam meg, hogy milyen nyelvi formával hozza a $\mathrm{H}$ tudtára az eseményt a B. Ez a 9-es szituációval rokonítható valamelyest, abban az értelemben, hogy egy visszautasítást foglal magában.

\section{8. szituáció (Partner/titok)}

Itt 29 ígéret született, amelyek közül 11 direkt, ígérem formájú. A bocsánatkérések száma ebben a szituációban is igen magas, 34 adatközlő használta ezen jóvátevési aktust, mégpedig 21-en a Ne haragudj, 12-en a Sajnálom, és 3-an a Bocsi, vagy Bocsáss meg formulát. 3-an írták, hogy Szeretlek, és sokan alkalmaztak arculatvédő, mentegetőző vagy indokoló formát, pl. 6 válaszban is szerepel, hogy véletlen volt, 5-ben, hogy kicsúszott (a számból). A szándékosság hiányát és az önhibáztatást mutató eszközök is nagy számban fordultak elö: nem is fogtam fel, nem akartalak megbántani, nem figyeltem rá, mit beszélek, meggondolatlan vagyok, nem volt szándékos stb., valamint az előbbiekhez hasonló, beismerő és a $\mathrm{H}$-val egyetértő formulák is gyakoriak voltak, pl.: átérzem a helyzeted, teljesen igazad van, szörnyú dolog volt, amit tettem, tudom, milyen rosszul esik, megértelek stb. Ezekkel a stratégiákkal a következő részben fogok alaposabban foglalkozni.

13 Egy hasonló, de konkrétabb szituáció található Suszczyńska disszertációjában is (Suszczyńska 2010: 219. Sit 5.). 


\section{9. szituáció (Barát/sörözés)}

Itt nem volt nagyon szorosan megkötve a feladat, nem adtam instrukciót arról az adatközlőknek, hogy pontosan mit tudassanak a H-val, csupán a problémát, a körülményeket és a lehetőségeket ismertettem velük. Ebből adódóan a szituáció válaszaira nagy szórás jellemző: változatos stratégiákat alkalmaztak az adatközlők, melyek mindegyike valamilyen visszautasítást jelentett. Így ígéret sem nagy számban keletkezett, csupán 13-an produkálták, s közülük csak 3-an direkt formában. 8 bocsánatkérés született, fele-fele arányban bocs és ne haragudj formában.

A válaszok között nem egy olyan megnyilatkozással találkoztam, amely egyszerre többféle beszédaktust rejt magában. Például $A$ héten nem túl jó, de ígérem, hogy a következő héten rá fogok érni, és fizetem a sörödet is megnyilatkozásban a fizetem a sörödet is egyszerre ígéret és felajánlás, amely egyben kárpótlást is jelöl (jóvátevési aktus egyik stratégiájaként), ugyanez a helyzet a Eh, ne haragudj, el vagyok havazva, de a jövő héten meghívlak! megnyilatkozás jövő héten meghívlak részével is, a ...Jövő hét pénteken töltsünk el egy napot együtt viszont olyan kérés vagy felszólítás, amely egyben kárpótlás felajánlása a $\mathrm{H}$ részére.

\section{0. szituáció (Partner/barát)}

Újfajta ígérettípus mutatkozik ennél a szituációnál, ez a feltételhez kötött vagy feltételes ígéret. Általában indirekt módon nyilvánul meg (21-szer), de van egy direkt formájú alakot tartalmazó válasz is. Jellemzően a feladatban megadott feltételt írták újra az adatközlök, ez az „amilyen az adjonisten, olyan a fogadjisten”típusú válaszokat eredményezte, mégis többféle módon valósították meg ezt a feltételt. Találkozunk még olyan ígérettel, amely valamilyen ok-okozati viszonyt tár fel: Mivel szeretlek, miattad én is kedves leszek, van hasonlító: Úgy fogok viszonyulni hozzá, mint ő hozzám, és természetesen, önmagában is előfordul indirekt ígéretet tartalmazó megnyilatkozás: Nem leszek olyannal kedves, aki velem sem az. 4 válaszban találunk megengedést, tehát a $B$ szinte engedélyezi a $H$-nak, hogy időt tölthessen a barátjával, 2-ben kérést (hogy legyen kedvesebb a barát), és 2ben felajánlást. A felajánlás általában csak az igemódban különbözik az ígérettől, jellemzően a feltételes mód jele (-na, -ne, -ná, -né) és a ható képző (-hat, -het) előfordulása jelzi, vagy valamilyen kárpótlásul nyújtható cselekvésre felhívás (kérés, buzdítás, kérdés stb. ${ }^{14}$ ). Visszatérve a számottevő gyakorisággal előforduló feltételes (indirekt) ígéretekre, anyanyelvi intuícióm alapján feltételezem, hogy nem a „legerősebb” ígéretről van szó, ha beszélhetünk az intenzitás fokának meglétéről az ígéretnél. Maga a tény, hogy normális körülmények között nem tenné meg A-t a $\mathrm{B}$, még igazolja Searle elméletét, de az, hogy egy feltételhez van kötve a cselekedet megtétele, már nem tűnik teljesen tisztának. Nem tiszta abban az értelemben, hogy alapvetően nem kötelezettségvállalást jelez a $\mathrm{B}$, hanem azt, hogy csak akkor teszi meg a H számára előnyös tettet, ha bizonyos kívánalmak (feltételek, körülmények) már adottak lesznek (a jövőben). Amikor azt írta az egyik adatközlő, hogy megígérhetem, hogy... vagy már megígértem, nem számítanak ígéretnek, mert sem az igemód, sem az igeidő nem felel meg az ígéret cselekvésének végrehajtásához szükséges sikerességi feltételnek. A feltételhez szabott ígéreteknél azonban

${ }^{14}$ A korábban előforduló példák során is ezen jegyek alapján különítettem el a felajánlásokat az ígéretektől. 
kitűnik, hogy valódi ígéret történik, mert jövőre utaló, egyes szám, első személyben, kijelentő mód, jelen időben íródtak a megnyilatkozások. A határozatlanságot kifejező módosítószókat (leggyakrabban a talán-t) tartalmazó válaszok ennél a szituációnál egy feltételhez kötött megállapítást, kijelentést valósítottak meg.

\section{1. szituáció (Kistestvér/játék)}

Ebben a szituációban nehéz volt azonosítani a válaszokban rejlő ígéreteket, 27 esetben sikerült hozzávetőlegesen megállapítani az ígéret létrejöttét, s csupán kétszer találtam nyílt, direkt formájút a megnyilatkozásokban. A feladatban először egy visszautasítást implikáló helyzetet teremtettem, majd megadtam a H kívánságának teljesítésére vonatkozó időbeli és anyagi feltételeket, s adtam egy hasonló instrukciót, mint az 1. és 2. szituációban, miszerint Tudasd vele, hogy arra (a kistestvér szülinapjára - a szerző.) megveszed neki. Direkt visszautasítást (most nem tudom megvenni) csak 12 válaszban lehetett tetten érni, viszont 11-szer alkalmaztak indoklást a beszélők, amelyek szintén visszautasításnak tekinthetők.

\section{Eredmények, megfigyelések}

\subsection{Osztályozás}

A szituációkra adott válaszok elemzését az nehezítette, hogy a hagyományos DCT-kkel ellentétben a kutatásomban alkalmazott teszt végeredményben nem egyfajta aktust produkált, hanem - úgy, ahogyan a valós társalgásokban - több, egyszerre előforduló és egymásba kapcsolódó szekvenciákat alkotott. Searle és Vanderveken Foundations of Illocutionary Logic címü könyvükben is így fogalmaznak az aktusok előfordulásáról: „Ahogy az indirekt beszédaktusok is eléggé általánosak az élő nyelvhasználatban, így az élő nyelvhasználatban, az illokúciós aktusok aligha fordulnak elö önmagukban, viszont előfordulnak a társalgások vagy a diskurzusok hosszabb szakaszának egy részeként." ${ }^{15}$ (Searle-Vanderveken 1985: 11).

Habár nem meglepő, hogy nem önmagukban fordultak elő az ígéretek, (mint például a támadásokra adott bocsánatkérő/jóvátevő válaszok, vagy a kérések bizonyos szituációkban), mégis bővebb elemzést igényel, hogy mikor és milyen más szekvenciákkal együtt fordulnak elő. Így talán kielégítőbb választ kaphatok kutatásom fő kérdésére, hogy milyen az ígérés természete a magyar nyelvhasználatban, milyen csoportokra lehet osztani, és mikor használjuk azokat.

\footnotetext{
15 Just as indirect speech acts are quite pervasive in real life, so in real life, illocutionary acts seldom occur alone but occur as parts of conversations or larger stretches of discourse. (saját fordítás)
} 


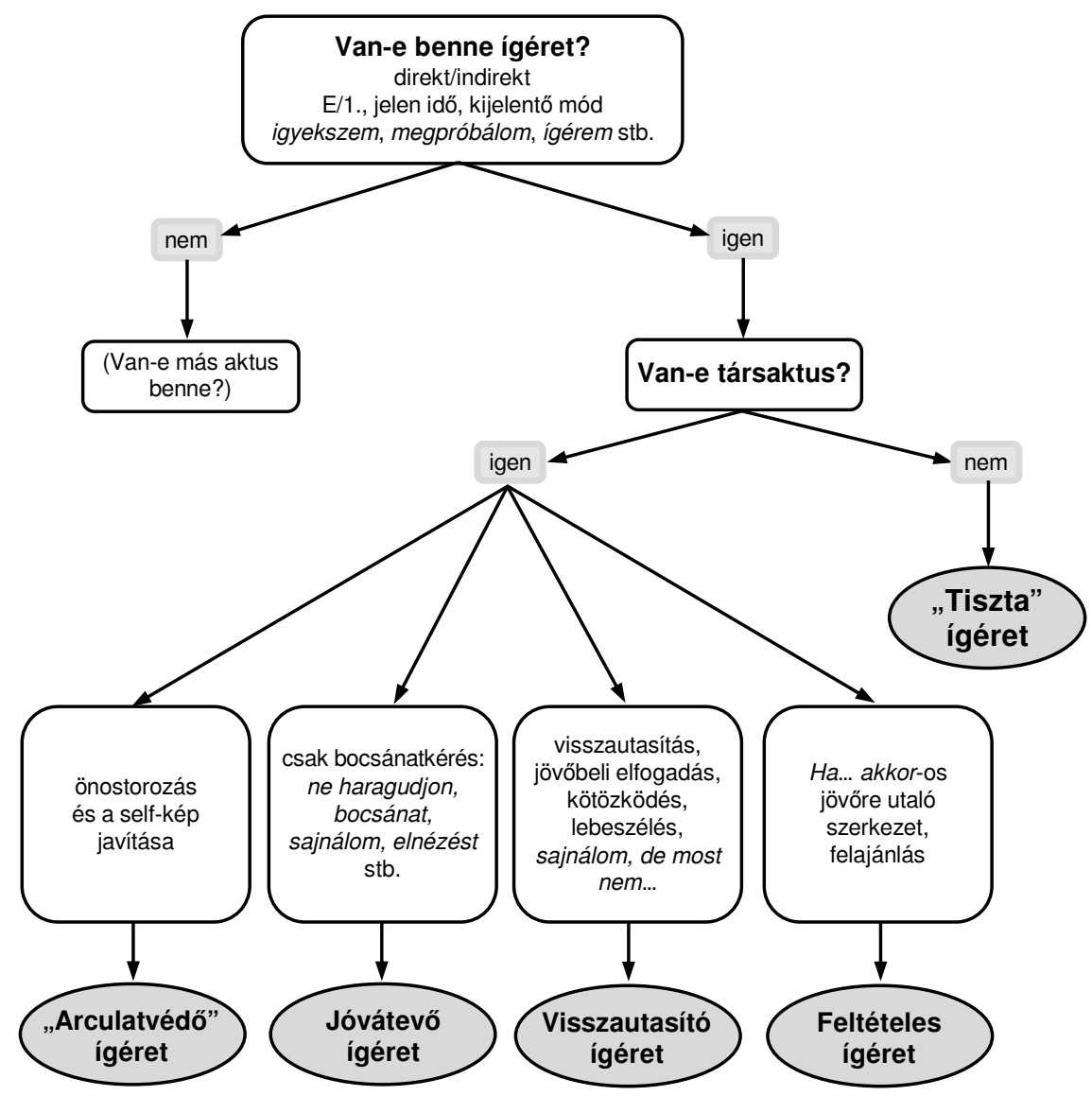

1. ábra. Az ígéret típusának meghatározása

Az írásbeli diskurzuskiegészítéses teszt kiértékelésénél a 1. ábrán látható folyamatábra szerint jártam el. Elöször a hagyományos terminológiát alapul véve az egyes válaszoknál (amelyeket a papír alapú tesztröl egy Excel-táblába gyűjtöttem szituációkra lebontva) megkíséreltem megállapítani, hogy megtalálható-e bennük performatív alakban vagy indirekten (E/1., jelen idő, kijelentő mód, jövőre utalva) az ígéret aktusa. Ha a válasz semmilyen formában nem tartalmazott kötelezettségvállalást, még mindig megvizsgáltam, hogy esetleg más aktus(ok) előfordul(nak)-e benne. Abban az esetben, amikor találtam ígéretet, akkor is megfigyeltem és feljegyeztem, hogy milyen más aktus szerepelhet még abban a megnyilatkozásban. Ha nem volt ilyen, akkor abban a válaszban egy vegytiszta ígérési aktust állapítottam meg. Ennél azonban gyakoribb, hogy ún. társaktussal együtt fordult elő az ígéret, ebben az esetben négy típusba lehetett elkülöníteni a megnyilatkozásokat. Az első típusban mindig találtam valamilyen kifejezést, ami a mentegetőzésre, túlzott indoklásra, önostorozásra, azaz a B valamilyen arculatóvására utalt. Élesen elválaszthatók 
voltak azok a megnyilatkozások, ahol az arcmunka jóvátevésben nyilvánult meg. Ezeknél csak bocsánatkérő aktusok álltak az ígéret mellett, általában performatív igékkel. A harmadik kategória is jól elkülöníthető társaktust eredményezett, olyan eseteket foglalt magában, amelyeknél valamilyen visszautasítást tesz a $B$, a $H$ látszólagos megnyugtatására pedig ígéretet tesz a visszautasítás után. A B részéről ezen megnyilatkozások voltak a legjobban arculatrombolók a $\mathrm{H}$ felé, hiszen nem egy adatközlő kötözködős hangvételben írta megnyilatkozását. Utolsóként megállapított kategória a feltételes ígéretek csoportja, ahol az ígéreteket egy feltétellel együtt, kizárólag a „ha..., akkor” formájú szerkezetekbe foglalták. Habár az arculatvédő társaktusok nem a legadekvátabb megnevezés az első csoportra, hiszen a jóvátevés aktusa is arculatmunka eredménye (sőt, még számos más beszédaktusé is), mégis jól szemlélteti ezt a különálló csoportot.

Ha a szituációkra adott, ígéretet tartalmazó válaszokat tekintjük, az alábbi csoportokat különíthetjük tehát el:

\begin{tabular}{|c|c|c|}
\hline Igéretek típusai & Szituációk & Társaktusok \\
\hline \multirow{2}{*}{$\begin{array}{l}\text { Arculatvédő } \\
\text { ígéretek }\end{array}$} & 1. (Barátok/referátum) & kérés/felszólítás, mentegetőzés \\
\hline & 2. (Tanár/referátum) & - \\
\hline \multirow{4}{*}{$\begin{array}{l}\text { Jóvátevő } \\
\text { ígéretek }\end{array}$} & 3. (Tanár/késés) & bocsánatkérés \\
\hline & 4. (Főnök/késés) & bocsánatkérés \\
\hline & 5. (Könyvtáros/könyv) & bocsánatkérés, köszönet \\
\hline & 8. (Partner/titok) & bocsánatkérés, arculatóvás \\
\hline \multirow[t]{4}{*}{$\begin{array}{l}\text { Visszautasító } \\
\text { ígéretek }\end{array}$} & 6. (Szaktárs/könyv) & $\begin{array}{l}\text { indirekt visszautasítás: sajnálat } \\
\text { kifejezése }\end{array}$ \\
\hline & 7. (Barát/pendrive) & sajnálat kifejezése, felajánlás \\
\hline & 9. (Barát/sörözés) & $\begin{array}{l}\text { direkt visszautasítás: nem } \\
\text { performatív, sajnálat kifejezése, } \\
\text { magyarázkodás }\end{array}$ \\
\hline & 11. (Kistestvér/játék) & $\begin{array}{l}\text { nem performatív visszautasítás, } \\
\text { felajánlás }\end{array}$ \\
\hline $\begin{array}{l}\text { Feltételes } \\
\text { ígéretek }\end{array}$ & $\begin{array}{l}\text { 10. (Partner/barát) } \\
\text { (11. részben) }\end{array}$ & engedélyezés/beleegyezés \\
\hline
\end{tabular}

2. táblázat. Az ígéretek típusai ${ }^{16}$

Az alábbiakban az egyes csoportokat fejtem ki és magyarázom, s minden szituációból egy-egy jellemző, sokszor hasonló módon előforduló példával szemléltetem.

1. Arculatvédő ígéretek

(6) Igyekszem érthetően átadni nektek, amit szeretnék, de ha kérdés van, szakítsatok félbe és kérdezzetek. 1. szituáció (Barátok/referátum)

(7) A múltkori alkalmakkor kicsit izgultam, de most már sokkal jobban fog menni.

2. szituáció (Tanár/referátum)

${ }^{16}$ A szituációk oszlopa csupán a jellemzően abban a szituációban előfordult ígéretcsoportot jelzi. A 11. szituáció például tartalmaz feltételes formájú ígéreteket is. 
Jóllehet, az ígéretek megjelenése önmagában valamiféle arculatvédő stratégia eszköze, én mégis így neveztem azokat a típusú ígéreteket, amelyek az első két szituáció válaszaiban fordulnak elő, s amelyekben dominál az arculatóvó stratégia (face work). Közös jellemzőjük, hogy nagymértékben önállóan fordulnak elő, s olyan helyzetekre adott reakcióban találhatjuk őket, amelyben a B egy negatív kritikára olyan megnyilatkozást tesz, amelyben próbálja a H-t meggyőzni arról, hogy tudomásul vette a kritikát és igyekszik pozitív irányba változni. Tehát megpróbálja a saját arculatát minél gyorsabban megvédeni és visszaállítani, ezzel remélve, hogy nem okoz újabb csalódást a közösségnek (H-nak).

2. Jóvátevő ígéretek

(8) Elnézést kérek, többet nem fogok késni.

3. szituáció (Tanár/késés)

(9) Ne haragudjon, többet nem fog előfordulni.

4. szituáció (Főnök/késés)

(10) Elnézést, teljesen kiment a fejemből. Holnap beviszem őket.

5. szituáció (Könyvtáros/könyv)

(11) Ne haragudj, többet nem fordul elö. Mivel engesztelhetnélek ki?

8. szituáció (Partner/titok)

Azon megnyilatkozásokat soroltam ebbe a csoportba, ahol az ígéret a jóvátevési aktus részeként jelenik meg, mégpedig a Fraser (1981) által meghatározott promise of forbearance kategóriaként, ahol a $B$ megígéri, hogy a problémás cselekedetet nem fogja megtenni a jövőben. Jellemzően olyan szituációkban fordul tehát elő, amelyben a $B$ valamilyen problémás dolgot tett vagy nem tett (nem vitte vissza a könyveket a könyvtárba, kifecsegett egy titkot stb.), s ezért jóvá kell tennie „bünét” H-nak. A (8)-(11)-es példák mindegyikében megfigyelhetjük a bocsánatkérés valamilyen formáját és az indirekt ígéretet. A (10)-esben még egy mentegetőzést, a (11)-es példában pedig egy jóvátétel felajánlását is láthatjuk. A jóvátevés aktusához természetesen hozzátartozik az arculatóvó stratégia, tehát nem furcsa, hogy ezen szituációkra adott válaszokban is nagy számban fordulnak elő mentegetőző, magyarázkodó, s úgy általában arculatvédő stratégiák. Érdekes, hogy kiugróan magas volt e szituációknál az ígéretek száma (átlagosan 34 válaszban a 40-ből), s azok együttes előfordulása a bocsánatkéréssel is hasonló arányú volt (25 együttes a 34-ből), míg a többi szituációnál átlagosan 20 válaszoló használt ígéretet. ${ }^{17}$

3. Visszautasító ígéretek

(12) Bocsi, de tudod, hogy csak jövő héten tudom visszahozni. Remélem nem sürgős. Nem direkt hagytam otthon! 6. szituáció (Szaktárs/könyv)

(13) Jaj, jó, h emlékeztetsz! Máskor írj föl nekem egy Cavintont. Holnap visszaadom! 7. szituáció (Barát/pendrive)

(14) Hú, az a helyzet, hogy a héten egyáltalán nem érek rá, tudod, vizsgaidőszak... bocsi! Jövő héten összehozzuk feltétlen!

9. szituáció (Barát/sörözés)

${ }^{17}$ Az általam megállapított kategorizálás alapján számolt értékek. 
Ezek az ígéretek akkor keletkeztek, amikor valamilyen visszautasító reakciót kellett produkálniuk az adatközlőknek ahhoz, hogy a szituációkban leírt feladatukat végrehajthassák. A visszautasítás stratégiáit Szili Katalin (2002) fordításában BeebeTakahashi-Uliss-Weltz (1990) kategorizálására alapozva vizsgáltam a nevezett szituációkban. Úgy használtam a kategóriákat, hogy a megnyilatkozások elejét vettem alapul, s azok alapján osztályoztam őket. Természetesen itt is megfigyelhető, hogy egyszerre többféle stratégiát alkalmaz a beszélő, jelen vizsgálatban azonban nem célom a visszautasítás különböző megnyilvánulásait kutatni, de annál fontosabbnak éreztem az ígéretet tartalmazó válaszok visszautasítási stratégiáit megfigyelni. Ugyanis van egy számomra fontos kategória az indirekt visszautasítási stratégiák között: jövőbeli elfogadás kilátásba helyezése (promise of future acceptance (Szili 2002: 206)). A 6. (Szaktárs/könyv), a 7. (Barát/pendrive) és a 11. (Kistestvér/játék) szituációkban összesen 17-szer kezdték ezzel a stratégiával a választ. Ennek példája a (15)-ös példamondat vagy a Jövő hét elején menne csak, Jövő hónapban visszatérünk rá stb. kezdetű megnyilatkozások. Ezenkívül számos más visszautasítási stratégiát alkalmaztak az ígéretet tartalmazó válaszokban: alternatíva felajánlása (Addig kiveszem neked a könyvtárból...), sajnálat kifejezése (l. (12)-es példa), látszólagos elfogadás vagy kertelés (Hátha szülinapodra teljesül a kívánságod), magyarázkodás/okadás (Tele vagyok tanulnivalóval...), kísérlet a partner lebeszélésére: kötözködés (Attól hogy minden nap emlékeztetsz, még nem lesz itt hamarabb), lebeszélés (Ez túl nagy ajándék ahhoz, hogy csak úgy megvegyem...), önvédelem (Nagyon szívesen mennék, de...) és együttérzés kiváltása (Öcsi, fogd már fel, hogy le vagyok égve!). De nemcsak indirekt formában találkozunk visszautasítással, ahogy azt a (14)-es példában a nem érek rá mutatja, vagy a 11-es szituációnál gyakran előforduló válaszokban felfedezhető Most nincs pénzem rá, Most nem tudom neked megvenni, Most nem veszem meg neked stb. kezdetű megnyilatkozások. Ezek nem performatív, direkt tagadási formák, ahol vagy a nem-mel tagadja a cselekedetet, vagy az akaratot/lehetőséget tagadja a nem tudom formával. Ritka, de előfordult, hogy a visszautasítást valamilyen tréfával fejezte ki a B, mint a (13)-as példában, ami a kikerülés stratégiájának verbális típusa (mint a kérés megismétlése vagy kertelés, témaváltás stb.).

A visszautasító ígéretek tehát azok az ígéretek, amelyeket akkor tesz a B, amikor a $\mathrm{H}$ kérésének el nem fogadását enyhíteni akarja egy jövőbeni elfogadás ígéretével vagy szándékával.

4. Feltételes ígéretek

(16) Ha ő is normálisan viselkedik velem, akkor én is az leszek vele.

10. szituáció (Partner/barát)

(17) Ha jól viselkedsz a következő hónapban, akkor születésnapodra megkapod tőlem.

11. szituáció (Kistestvér/játék)

Ez a típus nem egyedülálló, a szakirodalomban különféle módon nyilatkoznak róla. Al-Omari és Abu-Melhim (2013: 32) a jordániai arab nyelvben vizsgálták az ígéreteket, s négyféle ígéretet különítettek el: direkt ígérés (direct promising), kitérő 
ígérés (evasive promising), szatirikus ígérés (satirical promising) és feltételes ígérés (conditional promising). Antonio Blanco Salgueiro szerint a legjellemzőbb fenyegetések feltételként jelennek meg a természetben ( $\mathrm{Ha}$ nem adja ide a pénzt, lelövöm!), mely forma megjelenik a feltételes ígéreteknél is (Ha megcsinálod a házidat, elviszlek a filmre) (Salgueiro 2010: 217).

Searle azonban a felajánlások egy fajtáját nevezi kondicionális ígéretnek, amelyben a hallgató explicit elfogadásától függ az ajánlat tétele (Searle 1992: 10). Ezek alapján nem nyilvánítható ki teljesen egyértelműen, hogy a feltételes ígéret miként elemezhető: felajánlásnak vagy különálló ígéretfajtának. Jelen kutatásra alapozva az utóbbiról beszélhetünk a magyar nyelv esetében.

\subsection{A szociális tényezők és az ígéret kapcsolata}

Tanulmányomban az arculatvédő stratégiák megjelenésére figyelmet fordítva, megvizsgáltam a szociális paraméterek változtatásával keletkezett különbségeket a szituációkra adott válaszokban. Vizsgálatom nem teljes körü, csupán egy előzetes betekintést szeretnék nyújtani, ami alapot adhat egy későbbi, jóval részletesebb és pontosabb kutatáshoz.

\subsubsection{Szociális távolság}

A szociális távolságot (Social Distance) a legkisebbtől a legnagyobb távolságig csoportosítottam, így lett az első kategória a Bizalmas, az utolsó pedig az Idegen.

\section{Bizalmas}

Ilyen viszonyt jelenítenek meg a 8. (Partner/titok), a 10. (Partner/barát) és a 11. (Kistestvér/játék) szituációk. A 8. szituációban magasabb a bocsánatkérések száma, mint az ígéreteké (34 a 29-hez), a másik kettőben 22 és 27 ígéretet számoltam, de bocsánatkérő aktust egyet sem. Mindhárom szituációban különbözik a bizalmas viszony és a megtörtént eset/probléma súlyossága. A 8. feladatban találhatjuk a legsúlyosabb vétséget: a partner/kedves titkának az elárulását. Ezt jóvátevési aktusokkal próbálták enyhíteni az adatközlők. A 10. szituáció egy gyenge problémát fedett fel, sőt, szinte akár a $B$ érezhette támadásnak a párja barátjának viselkedését. Ezért úgymond „kegyeletből” felajánlotta párjának, hogy ha a 3. fél (a párja barátja) kedves lesz hozzá (B-hez), akkor viszonozni fogja a kedvességet. Az adatközlők valószínüleg nem érezték, hogy tehetnének a problémáról, ezért nem is próbáltak meg jóvátevési aktust alkalmazni. A 11-es szituácóra adott válaszokból is az derül ki, hogy a B meg akarja nyugtatni $\mathrm{H}$-t, de nem tartozik neki bocsánatkéréssel, viszont kompromisszumos megoldást választ: most visszautasítja, de a jövőben elfogadja a kérését.

\section{Barátok}

Ehhez a kategóriához leginkább két szituáció tartozik, a 7-es (Barát/pendrive) és a 9-es (Barát/sörözés). Ezek válaszai nagyon hasonlítanak egymásra: megközelítőleg ugyanannyi (12 és 13) ígéretet tartalmaznak, mindkettőben 20 és 30 közötti a mentegetőzések, magyarázkodások vagy okadások száma, a 7-ben azért kevesebb, mert ott többen adtak pozitív (elvárt) választ (Persze, itt van), s azokban kevesebbet mentegetőztek. Itt talán azért született kevesebb ígéret, mert a szituációk súlyossága nem közelítette meg pl. a 8. szituációét (nem volt árulás). 


\section{Szaktársak}

A szaktársak kategóriája már eggyel távolabb helyezkedik el a jó barátok halmazától, a hivatalos kapcsolatok egyik legbizalmasabb típusába sorolható. (Persze ez csak egy általánosítás, a való életben a bizalom és a szoros kapcsolat nem mindig a szociális távolságon múlik.) Ide az 1. (Barátok/referátum) és a 6 . (Szaktárs/könyv) szituációt soroltam, mégpedig azért, mert az egyetemi barátok nem feltétlenül tartoznak a legbelsőbb, legintimebb baráti körbe. Az 1-ben viszonylag magas az ígéretek száma (28), míg a 6-ban csupán 15 válasznál tudtam megállapítani elköteleződést, de 27-szer kértek bocsánatot, míg az elsőnél csak mentegetőztek és védték az arculatukat. Az arculatóvás kétféle stratégiája jellemzi tehát ezen szituációkat: a $B$ arculatának helyreállítása, valamint a $H$ távolító arcának óvása. $A$ két helyzet szintén komolyságban tér el egymástól, hiszen látható, hogy az elsőben igyekeztek „igyekvést mutatni”, azaz a hallgatók tudtára adni, hogy javítani szeretnék az előző hibájukat, míg a tartozásos szituációban nem érzik úgy, hogy nagy hibát követtek volna el a visszaadás késleltetésével.

\section{Diák - Tanár}

A 2. és a 3. szituációban találkozhatott az adatközlő ezzel a távolságtípussal. Míg a hallgató viszonylag többet érintkezik szaktársaival, tanáraival már nincs alkalma túl gyakran kommunikálni, ezért várhatóan máshogyan fog reagálni az efféle helyzetekben az adatközlő. A szakmai hibának számító rosszul tartott referátum kevésbé érintette rosszul a válaszolókat, mint a késéssel kapcsolatos, fenyegetőbb szituáció. Így a 2. szituációban csupán 20, a harmadikban 30 ígéret született, s bocsánatkérésekből is jóval több fordult elő az utóbbiban. A második szituációt az elsővel összehasonlítva érdekes adat, hogy a szaktársaknak többet ígértek, mint a tanárnak, a próbálom, igyekszem stb. igék viszonylag egyenlő számban fordultak elő, de amíg a szaktársak előtt nem kértek bocsánatot, addig a tanáros szituációban már megjelent néhány bocsánatkérés. Természetesen nem lehet figyelmen kívül hagyni, hogy a státuszkülönbségek is okozhattak eltérést ebben az esetben, erröl majd a következő, 6.2.2. pontban esik szó.

\section{Alkalmazott - Főnök}

Külön kategóriába tettem a 4. szituációt, mert egy gyakornokoskodó hallgató még távolabb helyezkedik el a főnökétől, mint a tanárától, hiszen a tanárral még mindig több kontaktust tud teremteni, mint a fönökkel, akit jó esetben alig lát az alkalmazott. A helyzet ugyanaz volt, mint a 3. szituációban, a késés miatt kirúgással fenyegették az adatközlőt. Ami alátámasztja az előbbi érvemet az az, hogy jelen esetben 39 ígéret és 33 bocsánatkérés született a válaszok között. ${ }^{18}$

\section{Idegen}

Az 5. szituációban a könyvtáros, aki ráadásul közvetett módon érintkezik a Bvel, a szociális távolság szempontjából legmesszebb van tőle, valószínűleg a hívás alkalmával volt először kontaktusuk. Ahogy már ismertettem, ennél a szituációnál lett a legtöbb, 40 ígéret, valamint bocsánatkérés, mentegetőzés és kérés is nagy számban fordult elő.

${ }^{18}$ Ezt az indokolhatja, hogy gyakornoki helyet jóval nehezebb újat keresni, mint egy szemináriumot elbukni és újracsinálni/helyettesíteni. 
Az elöbb ismertetettek összefoglalásaként az alábbi diagramon a három legfontosabb stratégiát emeltem ki a szociális távolság alapján: az ígéretet, a bocsánatkérést, illetve a mentegetőzést vagy indoklást, melyeket együttesen az angol face work terminus tükörfordításával, arcmunkával jelöltem. Ezeket az értékeket önmagukban számoltam, nem az ígérethez viszonyítva.

Bizalmas: 8., 10. és 11. szituáció

Barátok: 7. és 9. szituáció

৫ígéret 目Bocsánatkérés ¿Arcmunka (mentegetőzés, indoklás)

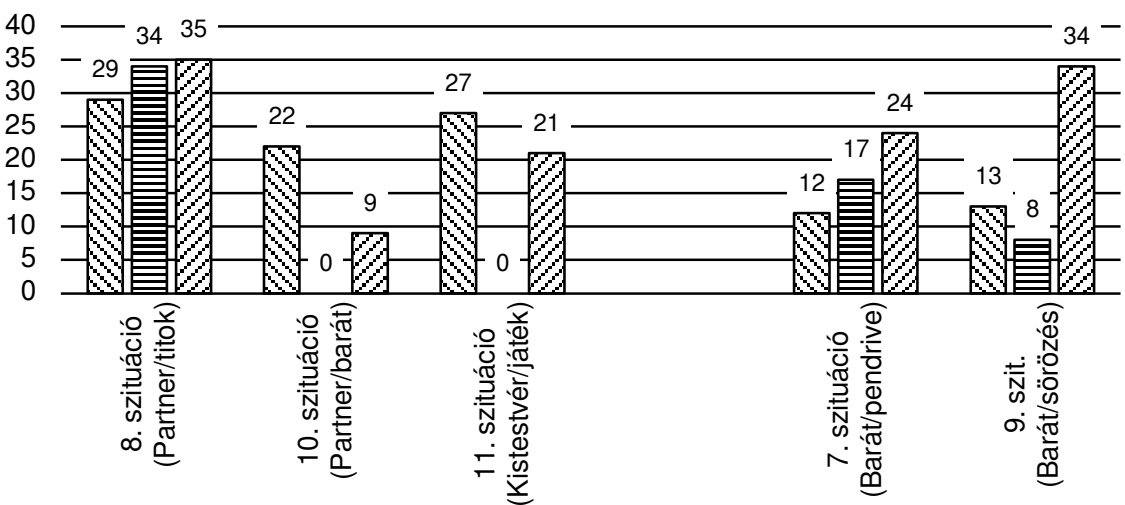

2. ábra. Kis szociális távolság, a H: bizalmas - barát

\section{Szaktárs: 1. és 6. szituáció Tanár: 2. és 3. szituáció Főnök: 4. szituáció Idegen: 5. szituáció}

₫ígéret घBocsánatkérés $\square$ Arcmunka (mentegetőzés, indoklás)

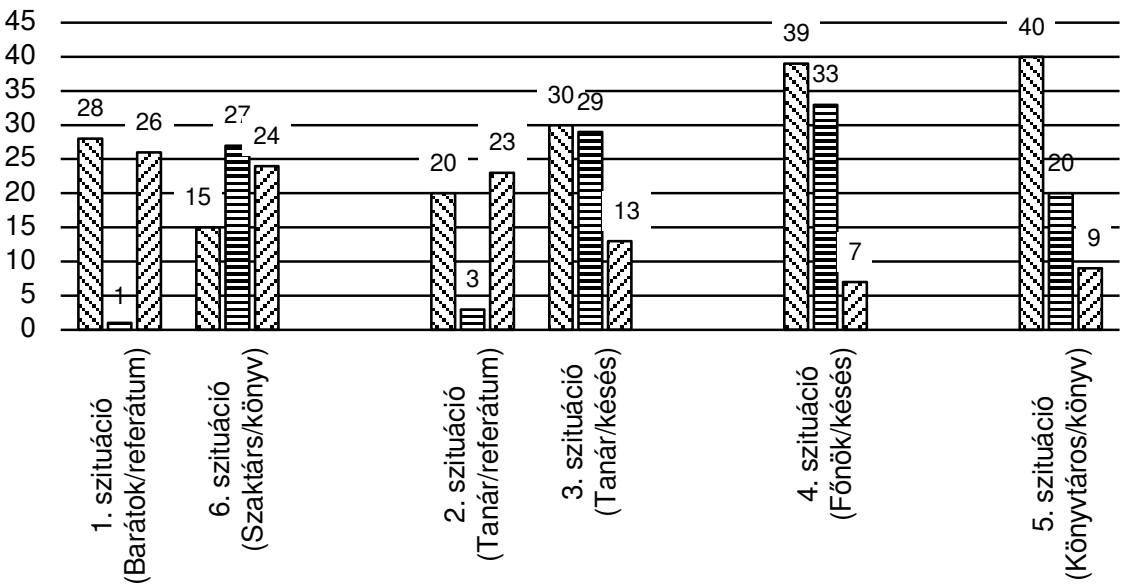

3. ábra. Nagy szociális távolság, a H: szaktárs - idegen 
A 2. és a 3. ábráról leolvasható, hogy az egyes szituációkban hogyan oszlott meg az ígéretek, a bocsánatkérések és az arcmunkák (mentegetőzés, indoklás) száma külön-külön, ezek az adatok továbbá a kontextuális jellemzőket (egyszerü bensőséges, csekély - súlyos probléma stb.) is jelzik. Láthatjuk, hogy a 8. (Partner/ titok) szituációban lett együttesen a legmagasabb a vizsgált aktusok száma, míg a hasonlóan bizalmas szociális távolságot megjelentető 10. (Partner/barát) és 11. (Kistestvér/játék) szituációkban egyáltalán nem született bocsánatkérés, s a másik két stratégiából is jóval kevesebb született. Szintén kevés bocsánatkérést, de több arcmunkát (mentegetőzést, indoklást) tartalmaznak az 1. (Barátok/referátum), a 2. (Tanár/referátum) és a 9. (Barát/sörözés) szituációk. Érdekes, hogy a B-töl legtávolabb álló személyekkel szemben bizonyos szituációkban (3. (Tanár/késés), 4. (Főnök/késés) és 5. (Könyvtáros/könyv)) szinte egyformán kiemelkedő az ígéretek és a bocsánatkérések száma, míg a mentegetőzésekből ezeknél találjuk a legelenyészőbb előfordulást.

Érdekes, hogy az egyes blokkokon belül mekkora eltérések vannak az adatokat illetően, viszont, vegyük figyelembe, hogy nemcsak a szituációk típusai különbözhettek ugyanannál a távolságú személynél (pl. a két szaktársas szituációnál), hanem a szociális erő/státusz is eltérhet (pl. a 11. (Kistestvér/játék) szituációban ugyanolyan kicsi a távolság, mint a 10. szituációban (Partner/barát), ám a társadalmi hierarchiában már alsóbb helyet foglal el a kistestvér a B-hez képest, míg a partner vele egyenrangú). Hogy teljes képet kapjunk az ígéretről a magyar nyelvhasználatban, valamint annak előfordulási lehetőségeiről és okairól, mindenképpen át kell tekintenünk, hogy a szociális státusz változásával milyen mértékben változtak a szituációkra adott válaszok.

\subsubsection{Szociális erő/státusz}

A társadalmi erő vizsgálatához szintén felhasználhatók az eddig mért, $s$ az 1 . és a 2. ábrán látható adatok, melyeket a státusz szerint újracsoportosítva a következő pontban lévő ábrákon figyelhetünk meg.

\subsubsection{A B szociális ereje kisebb, mint a $H$-é $(B<H)$}

Négy olyan szituációt gyártottam, amelyben a $B$ státusza alacsonyabb a $\mathrm{H}$-énál: a 2. és a 3. szituációkban a „felettes" a tanár, a 4. szituációban a gyakorlati főnök, az 5. szituációban pedig az intézményt képviselő könyvtáros személye. Mindegyik szituációnál meghatározó lett az ígéretek száma a válaszokban, a késős és a tartozásos szituációknál számottevő bocsánatkérés és kevesebb arcmunka (mentegetőzés, indoklás) keletkezett, a kevésbé komoly 2. szituációnál fordítva: alig kértek bocsánatot, viszont többen használtak arculatvédő stratégiát. Ezekből látszik, hogy a hasonló komolyságú helyzetekben, hasonlóan magas társadalmi erővel rendelkező személlyel szemben szinte egyformán reagáltak az adatközlök. 


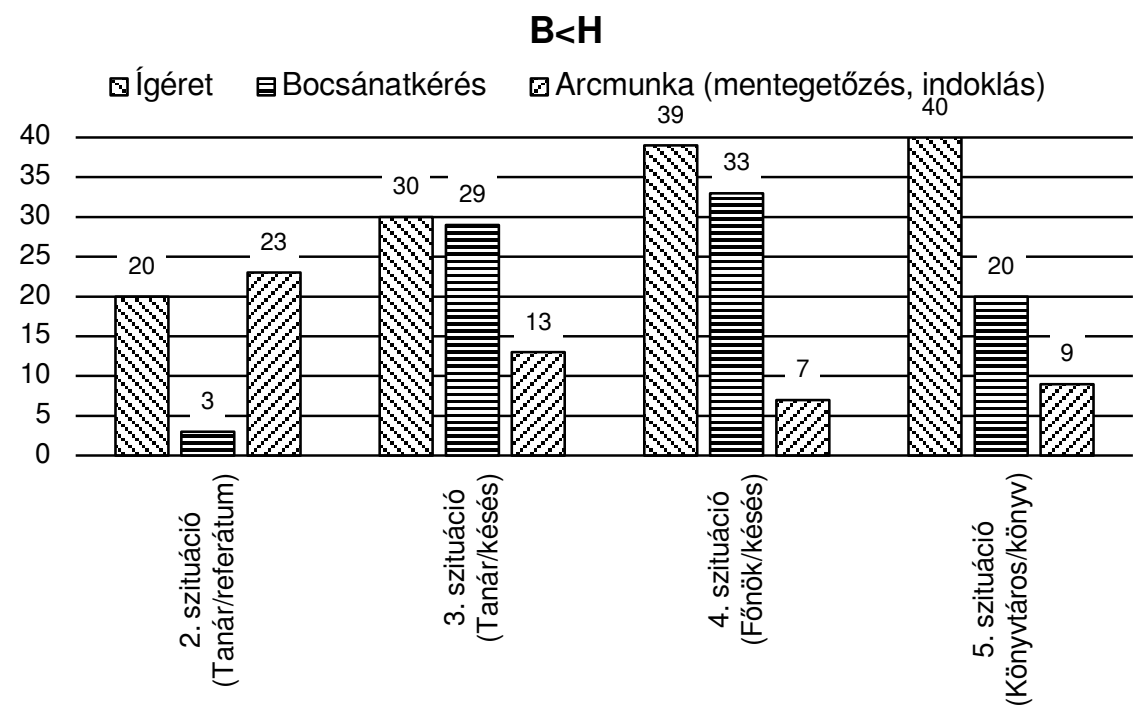

4. ábra. A szociális erőviszony: $B<H$

6.2.2.2. $A$ B szociális ereje megegyezik a $H$-éval $(B=H)$

Tesztemben a legtöbb szituációban a $\mathrm{H}$ azonos társadalmi erővel bír, mint a $\mathrm{B}$, pl. szaktársak, barát, partner (kedves). Itt is elmondható, hogy azokban az esetekben alkalmaztak ígérő, jóvátevő és/vagy arculatvédő stratégiát az adatközlők, amikor a támadást vagy problémát vélhetően súlyosabbnak itélték. Tehát a kedvesünk titkának kifecsegése és a szaktársunknak való tartozás sokkal intenzívebb reakciót váltott ki, mint a többi. Ebben a csoportban a legcsekélyebb stratégiát kiváltó szituációk az 1. (Barátok/referátum), illetve a 10. (Partner/barát) voltak. Mindkettőről elmondható, hogy nem teljesen egyértelmű a $B$ hibája, ezt valószínüleg a válaszolók is érzékelték. Míg az előbbiben viszonylag sokat ígértek, és számottevő a mentegetőzések száma, utóbbiban mindkét érték kicsivel kevesebb, viszont a bocsánatkérések száma elhanyagolható (az 1.-ben fordult elő csak 1), ami az elöbbi fejtegetéseimet igazolja. 


\section{$\mathrm{B}=\mathrm{H}$}

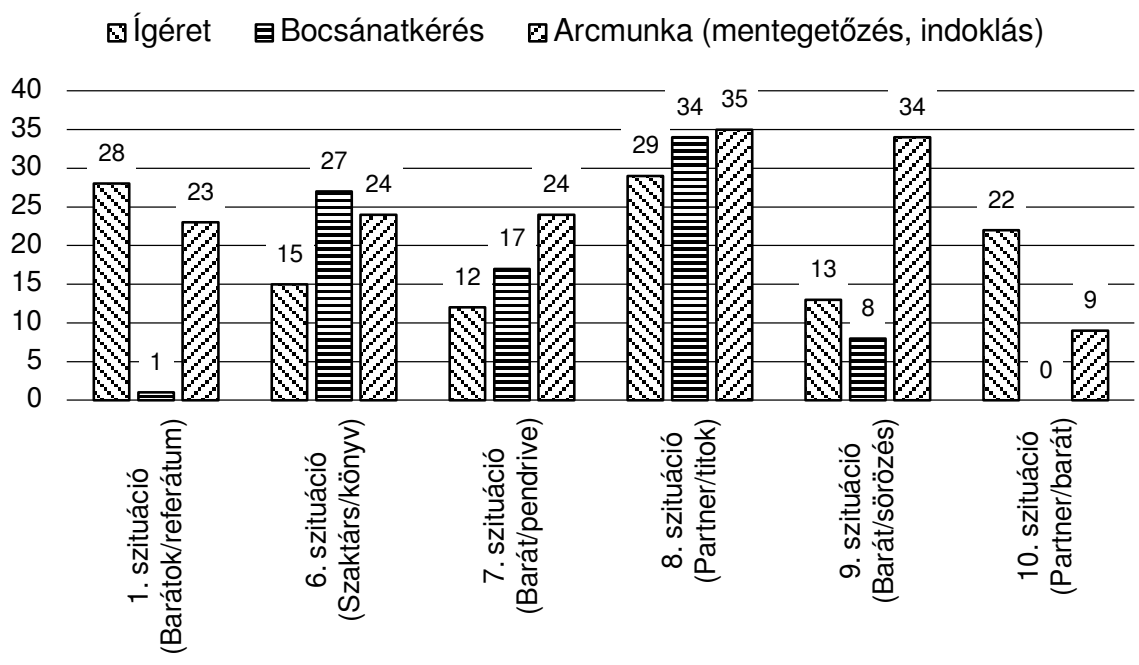

5. ábra. A szociális erőviszony: $\mathrm{B}=\mathrm{H}$

6.2.2.3. A B szociális ereje nagyobb, mint a $H$-é $(B>H)$

Kutatásomban egyetlen olyan szituációt írtam, amelyben a $B$ státusza magasabb a H-énál. Itt a H (azaz kistestvér) követelözését kellett visszautasítani, majd egy jövőbeli pillanatra hivatkozva elfogadni. Láthatóan nem volt akkora súlya a visszautasításnak, hogy akár egy adatközlőből is bocsánatkérést váltson ki. Ellenben igen nagy volt az előfordulása mind az ígéretnek, mint az arcmunkának (mentegetőzés, indoklás). Ebben hasonlít az 1. (Barátok/referátum) és a 10. (Partner/barát) szituációkra, hiszen ott sem született releváns számú bocsánatkérés.

\section{$\mathrm{B}>\mathrm{H}$}

₫Ígéret घBocsánatkérés 『Arcmunka (mentegetőzés, indoklás)

40

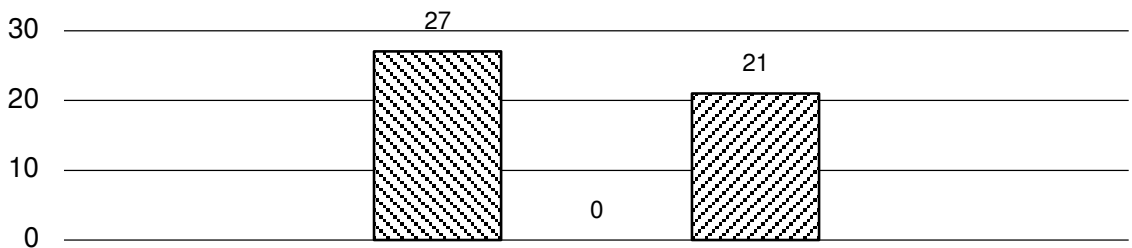

11. szituáció (Kistestvér/játék)

6. ábra. A szociális erőviszony: $\mathrm{B}>\mathrm{H}$ 


\section{7. Összegzés és diszkusszió}

Tanulmányomban arra próbáltam választ találni, hogy milyen módon használjuk az ígéret aktusát a mai magyar nyelvhasználatban, milyen kifejezésekkel alkotjuk meg, s milyen helyzetekben alakul ki az ígérés folyamata.

Cikkem első felében számot adtam a hagyományos és a legfrissebb szakirodalomban megjelent elméleti háttérről. Austint (1962/1990) érintve, Searle (1969/1997) munkásságát, az illokúciós aktusok feltételeit és szabályait igen részletesen és pontosan közöltem, majd egy újabb megközelítésből elemeztem tovább az ígéret aktusát. A 3. fejezetben az empirikus kutatás módszertanát ismertettem, a szakirodalom alapján elsősorban Suszczyńska (2010) disszertációjára támaszkodva. A 4. fejezettől kezdtem ismertetni az önálló kutatásomat. Előbb az ígéret aktusának problémáival foglalkoztam, abból is két jelenséggel: az ígéret és a jóvátevés különleges kapcsolatával, valamint az őszinte-őszintétlen ígéretek problematikájával. Az 5. fejezetben részletes betekintést nyújtottam az empirikus kutatásomba, egyesével elemezve a szituációkat. Végül az adatok többirányú kiértékelésével fejeztem be a munkát: megalkottam az általam kinyert válaszokban felfedezett ígéretek típusait, majd különböző szociális faktorok mentén újraelemeztem a kapott adatokat, részletesen, diagramokkal szemléltetve.

Előzetes feltevéseimre is sikerült válaszokat kapnom, melyeket a következőkben foglalok össze:

1. feltételezés: Azokban a szituációkban, ahol a H szociális státusza nagyobb, ott több ígéretet fognak közölni.

Nem egyenes arányosságban nőtt az ígéretek száma a szociális státusz nagyságával, de beigazolódott, hogy a legmagasabb társadalmi erőt képviselő személyekkel szemben kiugróan magas az ígéretek száma. Viszont nemcsak a státusz, de a szociális távolság és a kontextuális változók is meghatározták az ígéretek számát. A 3. (Tanár/késés), a 4. (Főnök/késés), az 5. (Könyvtáros/könyv) és a 8. (Partner/titok) szituációkban mondták a legtöbb ígéretet, ezek közül a 8. szituációban a távolság bizalmas, és társadalmilag egyenlő helyzetű a $\mathrm{H}$ a B-vel, de a sokkal súlyosabb témája miatt igényelte a vizsgált aktus használatát.

2. feltételezés: A hétköznapi, egyszerü szituációkban több ígéret lesz, mint az absztrakt, intim helyzeteknél.

Részben ez a feltételezés is teljesült, hiszen a rövidebb, hétköznapibb szituációknál (3. (Tanár/késés), 4. (Főnök/késés) és 5. (Könyvtáros/könyv)) látványosan több ígéret született, de a legösszetettebb és a legintimebb helyzetnél (8. (Partner/titok) szituáció) ugyanolyan magas számú ígéret keletkezett. Ez ugyanazzal magyarázható, mint az előző feltételezés eredménye: a válaszokat egyszerre szabja meg a szituáció komolysága, a szociális erő- és távolságviszonyok, valamint az adatközlő egyénisége és aktuális hangulata stb.

3. feltételezés: Az ígéret önmagában ritkán fordul elő, viszont egy másik aktus mellett (pl. jóvátétel, azon belül bocsánatkérés) nagyon gyakori lesz. 
Teljes mértékben igazolódott az általam generált szituációkban. Szinte nem keletkezett olyan válasz, amelyben az adatközlő ne alkalmazott volna egynél több beszédaktust vagy stratégiát. Ez a kutatásom szempontjából fontos megállapítás, mert így sikerült olyan helyzeteket teremtenem a szituációimban, amelyek többnyire életszerűek és elég általánosak voltak ahhoz, hogy megközelítőleg autentikus válaszokat nyerjek ki belölük. Ezt igazolják az olyan kifejezések, mint az Ó, Basszus, liíh, bocs-bocs, Jaj, Juj, A francba, Óó bocsi, Ú, ne haragudj, Fi-figyelj és a többi, indulatszót, káromkodást, vagyis valódi érzelmeket kifejező formák.

Tanulmányommal hozzájárultam a mai magyar nyelvhasználat még átfogóbb vizsgálatához. Kutatásom során kiderült, hogy a magyar nyelvhasználók változatos módon tesznek ígéretet. Jellemző tendencia, hogy valamely más aktussal szekvenciát alkotva találkozunk a vizsgált aktussal. A kutatás során világossá vált, hogy a természetes nyelvhasználatban nem jellemző a beszédaktusok izolált előfordulása. Ez jó alapot nyújt az újabb diskurzuskiegészítéses tesztek elvégzéséhez. A teszt során előforduló ígéretek többnyire valamilyen arculatóvó stratégiával kapcsolódnak össze. Ezen stratégiák függnek a probléma vagy támadás súlyosságától, továbbá attól, hogy hogyan és mire használják őket a beszélők.

A téma újszerüsége is azt mutatja, hogy számos lehetőség és út van a folytatásra. A továbbiakban a szociális tényezőket lenne érdemes még részletesebben tanulmányozni, valamint a gender-különbségeket megfigyelni, amelyre ebben a kutatásban nem volt módom, mert csak 3 férfi adatközlőm volt. Ezeken kívül célszerü lenne egy olyan kvalitatív teszt elvégzése, amelyben a válaszolók értékítéletet mondhatnának az ígéretek milyenségéről (pl. őszinteség vagy erősség dimenzióit tekintve). Tanulmányom úttörő a magyar nyelvészeti pragmatika szempontjából. Kutatásom hozzájárul a hatékonyabb kommunikációs stratégiák kialakításához, eredményeim így a közoktatásban és minden, kommunikációra épülő társadalmi tevékenység számára hasznosak lehetnek.

\section{Köszönetnyilvánítás}

Szeretném megköszönni Németh T. Enikő tanárnőnek a sok segítséget és az építő kritikát, valamint két bírálómnak a hasznos és konstruktív megjegyzéseket. A tanulmány elkészítésekor a TÁMOP-4.2.1.D-15/1/KONV-2015-0002 jövőkutatási ösztöndíjában részesültem.

\section{Hivatkozások}

Al-Omari, Sana Kamel - Abdel-Rahman Abu-Melhim 2013. Promising as a speech act in Jordanian Arabic. International Forum of Teaching and Studies 9/1:30-33.

Ariff, Tun Nur Afizah Zainal - Ahmad Ibrahim Mugableh 2013. Speech act of promising among Jordanians. International Journal of Humanities and Social Science 3/13:248-266.

Austin, John Langshaw 1962/1990. How to do Things with Words. [magyarul: Pléh Csaba (ford., szerk.) Tetten ért szavak. Budapest: Akadémiai Kiadó]. Oxford: Clarendon Press. 
Beebe, Leslie M. - Tomoko Takahashi - Robin Uliss-Weltz 1990. Pragmatic transfer in ESL refusals. In Robin C. Scarcella - Elaine Andersen - Stephen D. Krashen (szerk.) Developing Communicative Competence in a Second Language. New York: Heinle \& Heinle Publisher. 55-73.

Blum-Kulka, Shoshana - Juliane House - Gabriele Kasper 1989. Cross-Cultural Pragmatics: Requests and Apologies. Norwood: Ablex.

Egner, Inge 2002. The Speech Act of Promising in an Intercultural Perspective. (SIL Electronic Working Papers 2002-001). Dallas: SIL International. www.sil.org/resources/publications/entry/7825 (2015. 11. 25.).

Fraser, Bruce 1981. On apologizing. In Florian Coulmas (szerk.) Conversational Routine. Explorations in Standardized Communication Situations and Prepatterned Speech. The Hague: Walter de Gruyter. 259-271.

Hickey, Raymond 1986. A promise is a promise. Studia Anglica Posnaniensia 18:69-80.

Kecskés István 2003. Szavak és helyzetmondatok értelmezése egy dinamikus jelentésmodell segítségével. In Németh T. Enikő - Bibok Károly (szerk.) Általános Nyelvészeti Tanulmányok XX. Tanulmányok a pragmatika köréból. Budapest: Akadémiai Kiadó. 94-102.

Nowosielski Diána 2015a. Az ígéret beszédakcentusának vizsgálata a mai magyar nyelvhasználatban elméleti megközelítésben. In Bíró Gyöngyvér (szerk.) Móra Akadémia Szakkollégiumi Tanulmánykötet. Szeged: SZTE Móra Ferenc Szakkollégium. 34-50.

Nowosielski Diána 2015b. Az ígéret beszédaktusa. In Melhardt Gergő - Szabó Gergely (szerk.) Juvenália: kettő-három. Budapest: Eötvös Collegium Magyar Mühely. 81-92.

Salgueiro, Antonio Blanco 2010. Promises, threats, and the foundations of speech act theory. Pragmatics 20/2:213-228.

Searle, John R. 1969/1997. Az illokúciós aktusok szerkezete. In Pléh Csaba Síklaki István - Terestyényi Tamás (szerk.) Nyelv - kommunikáció - cselekvés. Budapest: Osiris Kiadó. 43-52.

Searle, John R. 1976. A classification of illocutionary acts. Language in Society 5/1:1-23.

Searle, John R. 1992. Conversation. In Herman Parret - Jef Verschueren (szerk.) (On) Searle on Conversation. (Pragmatics \& Beyond New Series 21). Amsterdam: John Benjamins Publishing Company. 7-30.

Searle, John R. - Daniel Vanderveken 1985. Foundations of Illocutionary Logic. Cambridge: Cambridge University Press.

Suszczyńska, Małgorzata 2003. A jóvátevés beszédaktusai a magyarban. In Németh T. Enikő - Bibok Károly (szerk.) Általános Nyelvészeti Tanulmányok XX. Tanulmányok a pragmatika köréból. Budapest: Akadémiai Kiadó. 255294.

Suszczyńska, Małgorzata 2010. Remedial Work in Hungarian. A Case Study. Doktori értekezés. Szeged: Szegedi Tudományegyetem.

Szili Katalin 2002. Hogyan is mondunk nemet magyarul? Magyar Nyelvör 126/2:204-220. 
Szili Katalin 2004. Tetté vált szavak. A beszédaktusok elmélete és gyakorlata. (Segédkönyvek a nyelvészet tanulmányozásához 36). Budapest: Tinta Könyvkiadó.

Turnbull, William 2001. An appraisal of pragmatic elicitation techniques for the social psychological study of talk. The case of request refusals. Pragmatics 11/1:31-61.

\section{Függelék}

(Diskurzuskiegészítéses teszt) $^{19}$

Kedves Válaszoló!

Nowosielski Diána harmadéves magyar BA szakos hallgató vagyok, és szeretném a segítségedet kérni a szakdolgozatomhoz. A feladatod annyi, hogy olvasd el figyelmesen a szituációkat, képzeld bele magad mindbe, és a „Te:” után írj mindegyikhez egy-egy olyan választ, amit abban a helyzetben mondanál. Kérlek, NE azt írd, hogy mit hogy csinálnál, hanem hogy mit MONDANÁL válaszul az elképzelt párbeszédben. (nyugodtan káromkodhatsz is! (:))

Kérlek, ha valami nem volt érthető, vagy zavaró volt, vagy csak kellemetlenül érezted magad teszt közben, írd le a megjegyzésbe a köv. lap alján. Köszönöm!

Korod: év

Nemed: $\square$ férfi $\quad \square$ nő

Nagy rohanásban indulsz el az egyetemre, nem nagyon figyelsz oda, hogy mit vettél fel. Amikor beérsz, a szaktársaid megdicsérnek, hogy milyen jól nézel ki ma.

Te:

1. (Barátok/referátum) Referátumot tartottál, ami után arra panaszkodtak barátaid, hogy nehezen értették az előadásod. A következő alkalommal, amikor előadsz, szeretnéd a tudomásukra hozni, hogy ezúttal érthetőbben fogod előadni a mondandódat, ezért így kezded:

Te:

4. (Főnök/késés) Első munkahelyeden gyakornokoskodsz, már harmadjára érkezel késve, amikor a főnököd közli veled, hogy ha még egy ilyen elöfordul, akkor ki fog rúgni.

Te:

Egyik barátod meghív mozizni estére. Tudod, hogy rengeteg dolgod van aznap, másnap 8-ra mész, ezért nem akarsz menni.

Te:

19 A szituációk sorrendjét megtartottam, de számozásukat eltöröltem, s a tanulmányban használatos számozásra és hivatkozásra cseréltem a jobb követhetőség miatt. 
2. (Tanár/referátum) Az egyik órán minden héten kell tartani egy rövid prezentációt. A múltkori két alkalommal azt mondta a tanárod, hogy túl sok ideig beszéltél, nem volt összeszedett az előadásod. Szeretnéd a tudomására hozni, hogy jobban felkészültél, és rövidebbre fogod a mondandódat.

Te:

3. (Tanár/késés) Notórius késő vagy, a tanárod azzal fenyeget, hogy kirúg a szemináriumról, ha nem érsz be legközelebb pontosan az órára.

Te:

Egyik barátnőd vett egy új nadrágot. Amikor találkoztok, direkt azt veszi föl és nagyon jól áll neki.

Te:

5. (Könyvtáros/könyv) Könyvtári tartozásod van. Felhív az egyik ott dolgozó, hogy két hónapja lejártak az általad kivett antik/drága könyvek, és ha három munkanapon belül nem viszed őket vissza, akkor plusz büntetést fognak kiszabni a késedelmi díj mellé.

Te:

6. (Szaktárs/könyv) Kölcsönkérted az egyik szaktársad egy könyvét, a téli szünetben otthon hagytad, azóta meg elfelejtetted visszahozni Szegedre. A szaktársad követeli vissza, de te csak a következő hétvégén mész haza, csak utána tudod visszaadni.

Te:

7. (Barát/pendrive) Kölcsönkérted a legjobb barátod pendrive-ját. A pendrive már hónapok óta nálad van. Amikor legközelebb összefuttok, megkérdezi, hogy hoztad-e a pendrive-ját, mert neki már nagyon szüksége van rá.

Te:

Reggel késve indulsz az egyetemre, és le is késed a buszodat. Épp arra jár az egyik barátod autóval, és felajánlja, hogy elvisz téged a suliig.

Te:

8. (Partner/titok) Egyik este, miközben a barátoddal beszélgettél, véletlenül kifecsegted a párod egyik féltett titkát. Hamarosan ez a párod fülébe jut, aki nagyon megharagszik rád, teljesen elárultnak érzi magát. Amikor legközelebb találkoztok, meg is jegyzi ezt neked. Ezután rádöbbensz, hogy mennyire megbántottad, és átérzed az ő helyzetét. Azt szeretnéd, ha ez lett volna az utolsó ilyen alkalom. Mit mondasz neki?

Te:

9. (Barát/sörözés) A legjobb barátod megkérdezi tőled, hogy elmész-e vele sörözni, mert nagyon kevés időt töltesz vele mostanában. A héten sok tanulnivalód lesz, de szeretnél vele menni. De látod, hogy ezen a héten nem fog összejönni, de tudod, hogy lesz még alkalom, hogy rá fogsz érni. Te: 
Előadáson ülsz, és jegyzetelés közben fogyott ki az egyetlen tollad. A melletted ülőnek, akit nem ismersz, látod, tele van a tolltartója tollakkal. Te:

10. (Partner/barát) A párod legjobb barátja féltékeny rád, mert szerinte miattad tölt kevesebb időt vele a párod. De megmondta a párodnak, hogy kedves lesz veled. Értesd meg a pároddal, hogy abban az esetben, ha a barátja kedves lesz veled, Te is viszonozni fogod a kedvességét.

Te:

11. (Kistestvér/játék) Kistestvéred a bevásárlóközpontban kinézett magának egy játékot. Látod, hogy nagyon szeretné tőled megkapni, szinte követelőzik, de azt is tudod, hogy neked erre most nincs pénzed. A következő hónapban van a születésnapja. Tudasd vele, hogy arra megveszed neki.

Te:

Köszönöm szépen a segítségedet! :)

Megjegyzés, vélemény:

\section{A szerzőről}

Nowosielski Diána a Szegedi Tudományegyetem Bölcsészettudományi Karának Elméleti nyelvészet mesterszakos hallgatója. Jelenlegi kutatási területe a pragmatika, azonban folyamatban lévő vizsgálódásait szeretné neuro-, illetve pszicholingvisztikai aspektusokkal is kiegészíteni.

Elérhetősége: nowosielski.diana@gmail.com 